\title{
PLATAFORMA 'CONSUMIDOR.GOV.BR' E A INTERPRETAÇÃO PELOS TRIBUNAIS ESTADUAIS: INTERFACE ENTRE DESJUDICIALIZAÇÃO DOS CONFLITOS DE CONSUMO, ACESSO À JUSTIÇA E O DIREITO DO CONSUMIDOR ${ }^{1}$
}

\author{
'CONSUMIDOR.GOV.BR' PLATFORM AND THE INTERPRETATION \\ BY THE STATE COURTS: INTERFACE BETWEEN THE REDUCED \\ JUDICIAL INVOLVEMENT IN CONSUMER CONFLICTS, ACCESS \\ TO JUSTICE AND THE CONSUMER LAW
}

Cláudio José Franzolin ${ }^{2}$

Thabata Turatti ${ }^{3}$

\begin{abstract}
RESUMO
A Constituição Federal incorporou dentre os direitos fundamentais, em seu artigo $5^{\circ}$, o dever do Estado de promover a defesa do consumidor. Essa defesa impõe uma compreensão mais expandida e contemporânea da tutela jurídica, o que reflete na necessidade de incorporar tanto o acesso à justiça quanto a busca pelos mais variados meios de solução de conflito de consumo. Nesse contexto, surge, como uma das novas formas de se tentar solucionar conflitos de consumo, a plataforma consumidor.gov.br. Este artigo visa contribuir no estudo da dita plataforma, quanto ao seu impacto no Poder Judiciário Brasileiro, e também, a partir das decisões judiciais colhidas, com algumas considerações e levantamento sobre seu papel na desjudicialização dos conflitos consumeristas. Por meio dessa análise, pretende demonstrar a relevância dela para o aperfeiçoamento da tutela do consumidor, enquanto uma ferramenta eletrônica disponível na internet, com o intuito de aproximar o consumidor do fornecedor. Para esse fim, o método adotado será o qualitativo-documental, mediante o levantamento de acórdãos judicias, e a forma de abordagem será hipotética-dedutiva.
\end{abstract}

PALAVRAS-CHAVE:

Plataforma consumidor.gov.br - Desjudicialização dos conflitos de consumo - direitos humanos do consumidor - acesso à justiça.

\footnotetext{
${ }^{1}$ Os autores agradecem a Puc-Campinas e o CNPq pelo apoio e financiamento à pesquisa, sendo este estudo o resultado parcial do desenvolvimento do projeto de pesquisa no período Ago/2019-Jul/2020.

${ }^{2}$ Doutor e mestre em Direito pela Puc-São Paulo. Professor titular Pesquisador do Programa de Pós-Graduação em Direito da Puc-Campinas (PPGD-Puc-Campinas) e professor na graduação de direito civil e consumidor. Associado do Instituto Brasileiro de Política e Direito do Consumidor (BRASILCON), do Instituto de Direito Privado (IDP), do Instituto "O Direito por um Planeta Verde", do Instituto Brasileiro de Direito Civil (IBDCivil) e do IBERC-Instituto Brasileiro de Responsabilidade Civil. E-mail: cfranzol30@ gmail.com.

${ }^{3}$ Graduanda do $8^{\circ}$ Semestre da Faculdade de Direito da Pontifícia Católica Universidade de Campinas. Fez Iniciação Cientifica da Puc-Campinas na modalidade de Bolsista PIBIC/CNPq, sob a orientação do Prof. Dr. Claudio Jose Franzolin. Integrante do Grupo de Pesquisa (CNPq) "Direito e Realidade Social". E-mail: thataturatti@gmail.com
} 


\begin{abstract}
The Constitution of the Federative Republic of Brazil incorporated among the fundamental rights, in the article $5^{\text {th }}$, the duty of the State to promote the consumer protection. This defense imposes a more expanded and contemporary understanding of legal protection, which reflects the need to incorporate both access to justice and the search for the most varied means of resolving consumer conflict. In this context, the platform consumidor.gov.br emerges as one of the new ways of trying to resolve consumer disputes. This article aims to contribute to the study of this platform, regarding its impact on the Brazilian Judiciary, and, also, from the judicial decisions collected, with some considerations and survey about its role in the reduce of judicial involvement in consumer conflits. Through this analysis, it intends to demonstrate its relevance for the improvement of consumer protection, as an electronic tool available on the Internet, with the purpose of bringing the consumer closer to the supplier. For this purpose, the method adopted will be the qualitative-documentary, through the collection of judicial judgments, and the form of approach will be hypothetical-deductive.
\end{abstract}

\title{
KEYWORDS:
}

Consumidor.gov.br platform - Reduced judicial involvement in consumer conflicts Consumer human rights - Access to justice.

\section{INTRODUÇÃO}

No atual contexto social, inserido na denominada sociedade de hiperconsumo"4, destaca-se o consumo, o qual está cada vez mais associado aos equipamentos e recursos digitais e desponta as mais variadas estratégias, como novas práticas comerciais ${ }^{5}$, "diversificação galopante de ofertas"6, "hipermarcas"7, a obsolescência planejada ${ }^{8}$; ainda, despontam-se na

${ }^{4}$ LIPOVETSKY, Gilles. A felicidade paradoxal: ensaios sobre a sociedade de hiperconsumo [Trad. Maria Lucia Machado]. São Paulo, Companhia das Letras, 2007, p. 25.

5"Outros modelos sugeridos para a precisão desta noção de bem-estar do consumidor privilegiam a prevalência da liberdade de escolha". (MIRAGEM, Bruno. Curso de Direito do Consumidor. São Paulo, Revista dos Tribunais, 2016, p 109).

${ }^{6}$ LIPOVETSKY, Gilles. A felicidade paradoxal. Ob cit. p. 46.

${ }^{7}$ Segundo o autor, hipermarca é a marca mundial, marca que mobiliza orçamentos de comunicação da mesma ordem de grandeza que as despesas ligadas à produção industrial, enfim, megamarcas ou hipermarcas presentes nos continentes, as quais baseiam-se "em um marketing global, em produtos e slogans, logotipos e imaginários geridos de maneira internacional e mais ou menos adaptada às especificidades locais" (LIPOVETSKY, Gilles. A felicidade paradoxal. $\mathrm{Ob}$ cit. p. 77).

${ }^{8}$ SLADE, Giles. Made to break: technology and obsolescence in America. Cambridge, Harvard University Press, 2006. 
dinâmica do consumo associada às tecnologias novas, a "economia de compartilhamento"9 e o comércio eletrônico.

Por outro lado, acentuam-se as frustrações e os conflitos em virtude dos vícios e defeitos nos produtos e serviços no âmbito das relações de consumo, tais quais, vício de inadequação, vícios informacionais; falta de segurança dos produtos ou serviços, publicidade enganosa, práticas abusivas, inadimplemento contratual pelo fornecedor ao não cumprir o ajustado acerca da prestação principal, falta de assistência pós-consumo etc.

Acrescentem-se, também, novos desafios da sociedade de consumo: circulação de dados, o superendividamento que tende a se acentuar em virtude dos impactos econômicos gerados pela pandemia do COVID-19 ${ }^{10}$, quando se verifica o risco de extinção de milhões de empregos $^{11}$; há também a globalização que repercute nas relações de consumo ${ }^{12}$ e as novas tecnologias.

Sob a perspectiva geral, conforme estudo do Conselho Nacional de Justiça realizado em 2019, a judicialização dos conflitos de consumo ocupou as primeiras posições na justiça

\footnotetext{
9“'Economia de compartilhamento, (...), como um sistema 'negocial' de consumo (collaborative consumption), no qual pessoas alugam, usam, trocam, doam, emprestam e compartilham bens e serviços, recursos ou commodities, de propriedade sua, geralmente com a ajuda de aplicativos e tecnologia online móvel, com a finalidade de economizar dinheiro, cortar custos, reduzir resíduos, dispêndios de tempo, ou a imobilização de patrimônio ou melhorar as práticas sustentáveis e a qualidade de vida em sua região (...)" (MARQUES, Cláudia Lima. A nova noção de fornecedor no consumo compartilhado: um estudo sobre as correlações do pluralismo contratual e o acesso ao consumo. Revista de direito do consumidor, v. 111: 247-268 (Mai-Jun/2017), em especial, p. 249).

${ }^{10} \mathrm{WHO}$ - WORLD HEALTH ORGANIZATION. WHO Director-General's opening remarksat the media briefing on COVID-19 (11/3/2020) [Disponível em: <https://www.who.int/dg/speeches/detail/who-director-general-sopening-remarks-at-the-media-briefing-on-covid-19---11-march-2020>Acesso: 8 abr 2020].

${ }^{11}$ Vale destacar a estreita relação da pandemia decorrente do COVID-19 com o endividamento do consumidor; afinal, "a crise que será econômica e trabalhista, poderá aumentar o número de desempregados no mundo em quase 25 milhões, segundo uma nova avaliação da Organização Internacional do Trabalho (OIT)" [NAÇÕES UNIDAS. OIT: quase 25 milhões de empregos podem ser perdidos no mundo devido à COVID-19 (18/3/2020). Disponível em: <https://nacoesunidas.org/oit-quase-25-milhoes-de-empregos-podem-ser-perdidos-no-mundo-devido-acovid-19/> Acesso: 13/4/2020].

12“'O certo é que, com a globalização, o Estado nacional territorial resta enfraquecido. Ficam tênues as fronteiras nesse mundo conectado em que ocorrem, dinamicamente, trocas de informações, por meio de redes de comunicação mundial, e se estabelecem relacionamentos entre os povos (antes inimagináveis) " (BELTRAME, Adriana; CHAIB; André Nunes; SILVA, René Marc da Costa Silva. O multiculturalismo e a globalização como princípios para uma internacionalização do direito. Padê, v. 2, n. 1, p. 4-46, jan./jun. 2008 [Disponível em: <https://www.publicacoesacademicas.uniceub.br/pade/article/view/583/531> Acesso 31 de dezembro de 2019].
} 
Estadual na primeira instância ${ }^{13}$. Só não é maior porque, segundo o Boletim SINDEC/2018 ${ }^{14}$, os PROCONS no Brasil, tem efetivo papel presente e atuante na coletividade.

Obviamente, que ante as reclamações dos consumidores, os fornecedores podem ou não adotar condutas de colaboração para solucionar o conflito. Mas, é preciso, antes de tudo, que esses canais sejam acessíveis e facilitados.

Uma das formas desenvolvidas para estreitar o contato entre consumidor e fornecedor é por meio da utilização da plataforma consumidor.gov.br ${ }^{15}$.

Dita plataforma desponta como uma ferramenta para ser manejada pelo consumidor que pretende, ante um dado problema, ter resposta do fornecedor. Ressalte-se, ademais, que o Decreto $10.1097 / 2020^{16}$, que altera o Decreto $8.153 / 2015$, passou a dispor no art. $1^{\circ}$-A, que o "consumidor.gov é a plataforma digital oficial da administração pública federal direta, autárquica e fundacional para a autocomposição nas controvérsias em relações de consumo" (g.n.). Ademais, no parágrafo primeiro, passa a estabelecer que "os órgãos e as entidades que possuam plataformas próprias para solução de conflitos de consumo migrarão os seus serviços para o Consumidor.gov.br até 31 de dezembro de 2020"17.

Merece realçar, atualmente, que dita plataforma se torna ferramenta que facilita o contato entre fornecedor e consumidor ante o isolamento social em decorrência da pandemia pelo Covid-19. Afinal, não só consumidores estão isolados em suas residências, mas também

\footnotetext{
${ }^{13}$ JUSTIÇA EM NÚMEROS 2019. Conselho Nacional de Justiça - CNJ (2019). (Disponível em: 〈https://www.cnj.jus.br/wp-content/uploads/conteudo/arquivo/2019/08/justica_em_numeros20190919.pdf>. Acesso 19 out. 2019).

${ }^{14}$ Esclareça-se que o Sistema Nacional de Informações de Defesa do Consumidor, é o sistema informatizado que integra o atendimento realizado por PROCONS de 26 estados, o do Distrito Federal e de 536 municípios, considerando, ainda, que há vários PROCONS com mais de uma unidade, assim, o sistema abrange 909 unidades espalhadas entre as 671 cidades brasileiras (BOLETIM SINDEC 2018. Secretaria Nacional do Consumidor SENACON, 2018, p. 6. (Disponível em: https://www.justica.gov.br/news/collective-nitf-content1552676889.94/arquivos/boletim-sindec-2018.pdf/view. Acesso 21 dez. 2019).

${ }^{15}$ BRASIL. DECRETO No 8.573, de 19 de novembro de 2015. Plataforma consumidor.gov.br. Dispõe sobre o Consumidor.gov.br, sistema alternativo de solução de conflitos de consumo, e dá outras providências. (Disponível em: http://www.planalto.gov.br/ccivil_03/_ato2015-2018/2015/decreto/D8573.htm Acesso em: 13 set. 2019).

${ }^{16}$ BRASIL. DECRETO No 10.197, DE 2 DE JANEIRO DE 2020, que altera o Decreto ${ }^{\circ} 8.573$, de 19 de novembro de 2015, para estabelecer o Consumidor.gov.br como plataforma oficial da administração pública federal direta, autárquica e fundacional para a autocomposição nas controvérsias em relações de consumo. [Disponível em: <http://www.planalto.gov.br/ccivil_03/_ato2019-2022/2020/decreto/D10197.htm> Acesso 13 janeiro 2020].

${ }^{17}$ Não é objeto desse trabalho fazer uma análise sobre ditos órgãos, nem de quais órgão se trata para se submeterem à dita plataforma, para não fugir do propósito de nosso estudo.
} 
empregados das empresas, comprometendo a eficiência dos canais de atendimento disponibilizados por elas para se comunicarem com seus consumidores.

Sensível a essa situação, a Secretaria Nacional do Consumidor do Ministério da Justiça e Segurança Pública, editou a Portaria n. 15, de 27 de março de 2020, e definiu no seu art. 1º, que as empresas providenciem o cadastro na plataforma consumidor.gov.br para viabilizar as comunicações delas com seus consumidores permitindo, também, a notificação online, conforme art. 34, do Decreto no 2.181, de 20 de março de $1997^{18}$.

A implantação da plataforma consumidor.gov.br bem como sua expansão enquanto canal de comunicação entre fornecedor e consumidor corresponde ao contexto social que estamos inseridos, denominado sociedade da informação ${ }^{19}$, ou seja, uma sociedade, cada vez mais associada aos equipamentos e recursos digitais, isto é, dita plataforma procura aproveitar essa realidade para que se potencialize o diálogo entre fornecedor e consumidor quando há um conflito de consumo.

O que desperta é que a internet propicia, entre fornecedores e consumidores, pela plataforma, processos mais simplificados de comunicação entre eles, por meio de mecanismos de interações online $e^{20}$.

Isto é, a internet incrementa uma alternativa real, célere, menos onerosa, menos burocrática para tentar solucionar conflitos de consumo, sem a necessidade de o consumidor deslocar-se de um local para outro. É nesse sentido que se destaca a importância da plataforma consumidor.gov.br ${ }^{21}$, fazendo-se necessárias maiores reflexões acerca dela e de sua possibilidade de desjudicializar os conflitos de consumo, uma vez que mesmo com o aumento de sua procura, são tímidas as manifestações sobre o assunto.

\footnotetext{
${ }^{18}$ BRASIL. Decreto n ${ }^{\circ} 2.181$, de 20 de março de 1997. Dispõe sobre a organização do Sistema Nacional de Defesa do Consumidor - SNDC, estabelece as normas gerais de aplicação das sanções administrativas previstas na Lei $\mathrm{n}^{\circ}$ 8.078, de 11 de setembro de 1990, revoga o Decreto $\mathrm{N}^{\circ}$ 861, de 9 julho de 1993, e dá outras providências. Disponível em: http://www.planalto.gov.br/ccivil_03/decreto/D2181.htm. Acesso em: 25 out. 2019.

${ }^{19}$ TOFFLER, Alvin. A terceira onda: a morte do industrialismo e o nascimento de uma nova civilização. [Tradução de João Távora]. Rio de Janeiro: Record, 2012, p. 183.

${ }^{20}$ É o que afirma BARROS, João Pedro Leite. Arbitragem Online em conflitos de consumo. São Paulo, Tirantto Blanch, 2019, p. 35.

${ }^{21}$ MINISTÉRIO DA JUSTIÇA E SEGURANÇA PÚBLICA. Aumentam os atendimentos em portal do Consumidor. Disponível em: https://www.justica.gov.br/news/collective-nitf-content-1551466308.51. Acesso em: 19 out. 2019.
} 
Esclareça-se que, a presente pesquisa ao levantar a variedade de decisões judiciais, busca demonstrar como os debates envolvendo acesso à justiça, direito do consumidor e a plataforma consumidor.gov.br são temas interdependentes e demandam reflexões a partir do contexto social e cultural $^{22}$ na maneira de os consumidores manejarem seus direitos diante de algum problema que eles possuem com os fornecedores. Para isso, o critério é o levantamento de decisões judiciais em segunda instância.

Para desenvolver a pesquisa o método adotado será o qualitativo-documental, por meio da coleta de acórdãos judicias de todos os Estados da Federação, em determinado espaço de tempo, que contenham em seu inteiro teor a expressão "consumidor.gov", seguindo o que Paulo Eduardo Alves da Silva (2017) sugere: “O levantamento de dados em autos de processos judiciais é uma vertente da técnica 'pesquisa documental'(...)"23, considerando que é importante considerar aplicação por meio de uma compreensão hipotética-dedutiva ${ }^{24}$.

O estudo, seguindo tal metodologia, não se concentra apenas na análise dos dados disponíveis na plataforma, avança-se no levantamento das decisões dos tribunais estaduais e os contornos argumentativos entre a obrigatoriedade ou a facultatividade no manejo da plataforma, como medida prévia à tutela jurisdicional pretendida pelo consumidor, analisam-se, assim, os julgados e também traçam-se considerações sobre a plataforma e sua articulação enquanto mecanismos de expansão de acesso à justiça e potencializadora para o consumidor estreitar diretamente diálogo com fornecedor e, assim, tentar resolver algum problema de consumo. Mas realçamos, que as considerações sobre a vulnerabilidade do consumidor, nesse contexto, só serão analisadas, em que pese a relevância, quando articulada com algum tema que se destaca, cujo intuito é fixar o estudo da interpretação pelos tribunais estaduais sobre o manejo da plataforma pelos consumidores.

Além disso, também revela a perspectiva funcional da plataforma ser centralizadora de informações e, assim, contribuir para ajudar o intérprete na condução de conflitos, os quais são

\footnotetext{
${ }^{22}$ Nesse sentido: IGREJA, Rebecca Lemos. O direito como objeto de estudo empírico: o uso de métodos qualitativos no âmbito da pesquisa empírica em direito. MACHADO, Maíra Rocha [Organização]. Pesquisar empiricamente o direito. São Paulo: Rede de Estudos Empíricos em Direito, 2017, p. 11-38, em especial, p 11.

${ }^{23}$ SILVA, Paulo Eduardo Alves da. Pesquisas em processos judiciais. MACHADO, Maíra Rocha [Organização]. Pesquisar empiricamente o direito. São Paulo: Rede de Estudos Empíricos em Direito, 2017, p. 275-320, em especial, p 277.

${ }^{24}$ MARCONI, Marina de. Andrade; LAKATOS, Eva Maria. Fundamentos de metodologia científica. 5. ed. São Paulo: Atlas S.A, 2003, em especial p. 95.
} 
sistemática e continuadamente noticiados na plataforma pelo consumidor diante, muitas vezes, de um mesmo fornecedor.

Ressalte-se, sim, a importância da plataforma como canal para estreitar a comunicação entre consumidor e fornecedor e, em que pese as críticas à plataforma, não econveredamos nesse sentido. A proposta deste estudo é mais modesta sob a perspectiva doutrinária e empírico baseado nas decisões judiciais.

Mas, também, e na medida do possível, destacamos como ela pode aperfeiçoar-se - ao menos, deveria - para promover novos rumos no acesso à justiça enquanto uma percepção mais ampla da tutela do consumidor; isto é, na medida em que se acentua a situação existencial de vulnerabilidade do consumidor, a plataforma precisa incorporar mecanismos protetivos, como por exemplo, para analfabetos e superendividados.

Em que pese as críticas lançadas à plataforma, o trabalho se debruça no levantamento e análise das decisões dos tribunais estaduais do país quanto o manejo obrigatório ou facultativo dela pelo consumidor antes do ajuizamento de uma demanda de consumo; mas, conforme a relevância de alguns julgados, também foram analisados alguns temas, embora não objeto desse trabalho, mas os quais estabeleceram alguma conexão de sentidos, ainda que indiretamente, por exemplo, dano moral, desvio produtivo do consumidor, entre outros.

\section{CRIAÇÃO DA PLATAFORMA CONSUMIDOR.GOV.BR.}

\subsection{Algumas considerações sobre o acesso à justiça e a perspectiva da Política Nacional das Relações de Consumo}

Antes de quaisquer considerações sobre a plataforma, vale destacar que o conceito de acesso à justiça, conforme pontua Mauro Cappelletti e Bryant Garth, em um primeiro momento, envolveria a preocupação com a paridade entre as partes, quanto aos instrumentos processuais à disposição para melhor tutela de direitos, ou seja, conforme os autores, "igualdade de armas"; 
porém, as diferenças entre as partes não têm como serem erradicadas ${ }^{25}$. É o que ocorre, nos conflitos de consumo, ante a assimetria entre fornecedor e consumidor.

O que merece ser realçado dos ensinamentos dos autores, é a concepção do que eles denominaram como a "terceira onda" do acesso à justiça.

Para os autores, o novo enfoque do acesso à justiça tem alcance mais amplo, ou seja, essa terceira onda inclui, ante os novos direitos e maior protagonismo para o cidadão, a necessidade de um "conjunto geral de instituições e mecanismos, pessoas e procedimentos utilizados para processar e mesmo prevenir disputas nas sociedades modernas"26; em suma, aumentar as possibilidades de melhoras de solução dos novos conflitos, já que novos interesses e novos direitos também implicam novos mecanismos procedimentais para pacificação social.

O Código de Processo Civil também se inspira numa nova concepção de acesso à justiça, conforme se depreende do seu art. $3^{\circ}$. Não é apenas o acesso ao Judiciário, mas incluem-se mecanismos de solução de controvérsias, isto é, assegurar ao cidadão outras formas, mais rápidas, econômicas, céleres e simplificadas de tentar solucionar um conflito instaurado.

Sob a perspectiva do direito do consumidor, por sua vez, o art. $5^{\circ}$, do CDC, contempla, dentre os elementos para a adequada efetivação da Política Nacional das Relações de Consumo, instrumentos como: assistência jurídica integral e gratuita para o consumidor carente; promotorias de justiça de defesa do consumidor no Ministério Público; delegacias de polícia especializadas para vítimas de infrações penais de consumo; Juizados Especiais e Varas Especializadas na solução de litígios de consumo e a criação e desenvolvimento das Associações de Defesa do Consumidor.

Nessa nova concepção e, tendo como foco a situação de vulnerabilidade do consumidor (art. $4^{\circ}, \mathrm{I}$, do CDC), não se pode perder de mira que se acentuam os desafios para o acesso à

\footnotetext{
25“'A efetividade perfeita, no contexto de um dado direito substantivo, poderia ser expressa como a completa 'igualdade de armas' - a garantia de que a conclusão final depende apenas dos méritos jurídicos relativos das partes antagônicas, sem relação com diferenças que sejam estranhas ao Direito e que, no entanto, afetam a afirmação e reivindicação dos direitos. Essa perfeita igualdade, naturalmente, é utópica. As diferenças entre as partes não podem jamais ser completamente erradicadas. A questão é saber até onde avançar na direção do objetivo utópico e a que custo. [...]." (GARTH, Bryant; CAPELLETTI, Mauro. Acesso à justiça [Trad. Ellen Gracie Northfleet]. Porto Alegre, Sergio Antonio Fabris, 1988, p. 15). A partir daí, os autores trazem algumas sugestões de soluções práticas para os problemas de acesso à justiça: assistência judiciária aos pobres, representação dos interesses difusos (Idem, passim, 31-66).

${ }^{26}$ GARTH, Bryant; CAPELLETTI, Mauro. Acesso à justiça. Idem, p. 67.
} 
justiça e, é nesse sentido, também, que os comentários apontados ao longo desse estudo se destacam, quando se aborda sobre a obrigatoriedade ou facultatividade do manejo da plataforma pelo consumidor antes dele ingressar com uma medida judicial. Como ensinam Carvalho e Bambirra, há a necessidade de estabelecer conexão entre acesso à justiça e vulnerabilidade:

Para tanto, ainda que louváveis as expectativas depositadas nos meios autocompositivos, diante das relações de consumo, será sempre pressuposto para sua aplicação o reconhecimento da vulnerabilidade. Ao que se propôs, o diálogo positivo dos meios autocompositivos com o acesso à justiça nos conflitos de consumo exige o reconhecimento da vulnerabilidade do consumidor como princípio basilar da Política Nacional das Relações de Consumo. Se diferente, os meios autocompositivos se tornam espaço que poderá inclusive agravar a vulnerabilidade do consumidor, não por uma condição que lhe é específica, mas pelo espaço que não lhe favorece, tampouco supre a sua vulnerabilidade ${ }^{27}$

Em suma, quando se analisa a plataforma e sua funcionalidade, é preciso considerar o contexto de acesso à justiça, pois, conforme Fernanda Tartuce, "o cerne do acesso à justiça não é possibilitar que todos possam ir a corte" 28 , mas, esclarece a autora, que a justiça possa envolver, a autotutela, por força da autocomposição, quando as próprias partes resolvem o impasse e, obviamente, também, quando há a um terceiro envolvido (árbitro ou magistrado).

Assim, para que se aperfeiçoe a plataforma, vale os ensinamentos de Verbicaro, quando realça a importância para o verdadeiro papel emancipatório no âmbito dos partícipes das relações de consumo, mas, reconhece o autor, a necessidade de que haja o aperfeiçoamento e normatização jurídica, além de avançar para um melhor balizamento das atuações administrativas e judiciais de todos os órgãos integrantes do sistema nacional das relações de consumo; e nesse estudo, tais ensinamentos, incluem-se, para a Plataforma consumidor.gov.br. ${ }^{29}$.

Nesse contexto, é que se avança para a análise da plataforma à luz das decisões estaduais

\footnotetext{
${ }^{27}$ CARVALHO, Diógenes Faria de; BAMBIRRA, Felipe Magalhães. Política Nacional de Defesa do Consumidor: apontamentos necessários entre as bases de proteção e os mecanismos de solução de conflito. Revista de Direito do Consumidor, vol. 128: 17-53 (Mar-Abr/2020), em especial, p.18.

${ }^{28}$ TARTUCE, Fernanda. Mediação nos conflitos civis. Rio de Janeiro, Forense, São Paulo, 2008, p. 97.

${ }^{29}$ VERBICARO, Dennis. Consumo e cidadania: identificando os espaços políticos de atuação qualificada do consumidor. Rio de Janeiro, Lumen Juris, 2017, p. 255.
} 
e da articulação com o acesso à justiça.

\subsection{A Plataforma consumidor.gov.br. e sua compreensão analítica}

A plataforma consumidor.gov.br desperta em meio ao contexto da, já citada, sociedade de informação. A sociedade de informação, conforme Adalto Ozaki e Eduardo Vasconcellos ${ }^{30}$, associa-se ao armazenamento, acesso e compartilhamento, cada vez maior, de informações de forma colaborativa e de qualquer lugar, enfim, dita realidade faz com que as empresas incorporem-na aos seus produtos e serviços, tecnologias. Afinal, estas ferramentas tornam mais fáceis a captação de dados para ágeis tomadas de decisões; além disso, essas tecnologias incrementam e simplificam, onde quer que as pessoas se localizam ${ }^{31}$, as comunicações entre elas (colaboradores, parceiros, consumidores). Destaque-se, porém, o dever de proteção dos dados pelas empresas, mas este aspecto não será abordado, em que pese a relevância na contemporaneidade (L. 13.709/2018 - Lei Geral de Proteção de Dados - LGPD).

Em meio a sociedade de informação a internet passou a ser uma importante ferramenta para o consumo, haja vista que, segundo o TIC Domicílios 2018, um terço dos usuários de internet no Brasil utilizam-se dela para ter acesso aos produtos e serviços ${ }^{32}$. Obviamente, que há também a exclusão social no âmbito da internet, os denominados, excluídos digitais, não abordados nesse estudo.

\footnotetext{
${ }^{30} \mathrm{~A}$ sociedade da informação é uma expressão que revela as tecnologias decorrentes de todo o aparato computacional - agora também nos celulares - que diz respeito à sociedade contemporânea, fundada na cultura da informação, na qual a padronização é rompida pela rede de computadores, que amplia os meios de comunicação "de máquina-para-máquina, para conversas entre seres humanos e ambiente inteligente ao seu redor" (OZAKI, Adalton; VASCONCELLOS, Eduardo. A revolução digital. In POLIZELLI, Demerval L; OZAKI, Adalton [Organizadores]. Sociedade da informação: os desafios da era da globalização e da gestão do conhecimento. São Paulo, Saraiva, 2008, p. 1-83 [Versão E-book]).

${ }^{31}$ Ozaki e Vasconcellos, citando, Manuel Matos, afirma que os computadores em si não constituem objetivo da rede; a internet é uma rede de pessoas. A partir daí, para os autores, "a internet somente teve esse estrondoso sucesso porque veio satisfazer uma necessidade contida na população e das empresas. Ela quebrou a barreira do confinamento. Com ela, o microcomputador pessoal deixou de ser o centro do repositório e processamento da informação e passou a ser uma porta de entrada para um universo maior, o conhecimento existente no mundo. A internet permite acessar e compartilhar informação e conhecimento (...)" (OZAKI, Adalton; VASCONCELLOS, Eduardo. A revolução digital. Ob cit. p. 11.)

${ }^{32}$ COMITÊ GESTOR DA INTERNET NO BRASIL. Pesquisa sobre o uso das Tecnologias de Informação e Comunicação nos domicílios brasileiros. Ob cit. p. 105.
} 
O que vale destacar é que a realidade online passa a se impor também como forma de potencializar como mecanismo para se tentar solucionar os conflitos de consumo.

Em que pese os PROCONS assumirem valiosa função social na tutela administrativa do consumidor, não concordamos com os apontamentos de João Paulo Alexandre de Souza. É que ele, citando entrevista feita com o então coordenador do SINDEC, à época da criação da plataforma (2014), ao comentar sobre o acesso facilitado à internet, afirmara que os consumidores não querem mais "se deslocar até um Procon, pegar senha, fila, (...), esperar a resposta do fornecedor, ir até o Procon receber a resposta e, então, dependendo da resposta, continuar o processo"33. Tal análise, salvo melhor juízo, não corresponde à realidade, porque após alguns anos de Plataforma, o consumidor continua recorrendo aos PROCONS, comprovando a relevância desses órgãos diante dos problemas cotidianos dos conflitos de consumo. Ou seja, a função social desse Órgão continua relevante e atuante.

$\mathrm{Na}$ verdade, nesse contexto de avanço tecnológico, a plataforma consumidor.gov.br, desponta como mais um meio a disposição do consumidor. Criada em 2014, por meio do Decreto $\mathrm{n}^{\mathrm{o}} 8.573^{34}$ e, tendo como fundamento legal o artigo $4^{\circ}$, inciso V do Código de Defesa do Consumidor ${ }^{35}$ e artigos $7^{\circ}$ inciso I, II e III do Decreto 7.963/2013 ${ }^{36}$, ela foi lançada com a promessa de facilitar e ampliar a interação entre o consumidor e o fornecedor.

A Secretaria Nacional do Consumidor, SENACON, do Ministério da Justiça, ficou responsável pela plataforma, mas, o seu monitoramento ficou à cargo "em conjunto com os

\footnotetext{
${ }^{33}$ Entrevista concedida pela Coordenadora Geral do SINDEC. Brasília, 23/10/2014, apud SOUSA, João Paulo Alexandre de. Defesa do consumidor e políticas públicas: um estudo sobre o Consumidor.gov.br. Monografia apresentada ao curso Gestão de Políticas Públicas. Universidade de Brasília, Brasília, 2014 (Disponível em: http://bdm.unb.br/bitstream/10483/9444/1/2014_JoaoPauloAlexandreDeSousa.pdf. Acesso em: 12 dez. 2019).

${ }^{34}$ BRASIL. DECRETO No 8.573, de 19 de novembro de 2015. Plataforma consumidor.gov.br. Dispõe sobre o Consumidor.gov.br, sistema alternativo de solução de conflitos de consumo, e dá outras providências. (Disponível em: http://www.planalto.gov.br/ccivil_03/_ato2015-2018/2015/decreto/D8573.htm. Acesso em: 16 dez. 2019).

${ }^{35}$ Art. $4^{\circ}$ A Política Nacional das Relações de Consumo tem por objetivo o atendimento das necessidades dos consumidores, o respeito à sua dignidade, saúde e segurança, a proteção de seus interesses econômicos, a melhoria da sua qualidade de vida, bem como a transparência e harmonia das relações de consumo, atendidos os seguintes princípios:(Redação dada pela Lei $n^{\circ}$ 9.008, de 21.3.1995): V - incentivo à criação pelos fornecedores de meios eficientes de controle de qualidade e segurança de produtos e serviços, assim como de mecanismos alternativos de solução de conflitos de consumo. (L. 8.078/90-CDC).

${ }^{36}$ Art. $7^{\circ} \mathrm{O}$ eixo de fortalecimento do Sistema Nacional de Defesa do Consumidor será composto, dentre outras, pelas seguintes políticas e ações: I - estimulo à interiorização e ampliação do atendimento ao consumidor, por meio de parcerias com Estados e Municípios; II - promoção da participação social junto ao Sistema Nacional de Defesa do Consumidor; e III - fortalecimento da atuação dos Procons na proteção dos direitos dos consumidores. (BRASIL. DECRETO No 7.963, de 15 de março de 2013. Institui o Plano Nacional de Consumo e Cidadania e cria a Câmara Nacional das Relações de Consumo. (Disponível em: http://www.planalto.gov.br/ccivil_03/_Ato2011-2014/2013/Decreto/D7963.htm. Acesso em 15 dez. 2019).
} 
PROCONS, Defensorias Públicas, Ministérios Públicos, Agências Reguladoras, entre outros órgãos públicos, e também por toda a sociedade"37.

\section{FUNCIONAMENTO E UTILIZAÇÃO DA PLATAFORMA CONSUMIDOR.GOV.BR.}

A adesão do fornecedor à plataforma, a priori, é voluntária, no entanto, em razão da situação de Pandemia do COVID-19, foi publicada a PORTARIA 15, de 27 de março de 2020 pelo Secretário Nacional do Consumidor do Ministério da Justiça e Segurança, a qual determinou ${ }^{38}$ o cadastramento de todos os fornecedores que se enquadrem aos perfis descritos no artigo $2^{\mathrm{o} 39}$, da dita Portaria.

O fornecedor, até antes da referida portaria, ao querer adentrar na plataforma, precisava aceitar o compromisso de que ele adotaria condutas de colaboração e consideração,

\footnotetext{
${ }^{37}$ CONSUMIDOR.GOV.BR.

QUEM

SOMOS.

(Disponível

em:

https://www.consumidor.gov.br/pages/conteudo/publico/4.Acesso em 15 dez. 2019).

${ }^{38}$ Vale ressaltar, porém, que, ante o período de pandemia, as empresas, com quadro reduzido de funcionários, além de atendimento reduzido junto aos mais diversos órgãos, sem contar as limitações de atendimento ao cliente diretamente com as empresas, a Portaria $\mathrm{n}^{\circ}$ 15, de 27 de março de 2020, determinou às empresas que elas providenciem o cadastro delas na plataforma consumidor.gov viabilizando então, pela Secretaria Nacional do Consumidor, a notificação, de forma eletrônica, nos termos do art. 34 do Decreto no 2.181, de 20 de março de 1997 (PORTARIA 15, de 27 de março de 2020).

39“'Art. $2^{\circ}$ Observado o disposto no §1o deste artigo, os seguintes fornecedores deverão cadastrar-se na plataforma Consumidor.gov.br até trinta dias contados da entrada em vigor desta Portaria: I empresas com atuação nacional ou regional em setores que envolvam serviços públicos e atividades essenciais, conforme Decreto 10.282 de 20 de março de 2020; II - plataformas digitais de atendimento pela internet dedicadas ao transporte individual ou coletivo de passageiros ou à entrega de alimentos, ou, ainda, à promoção, oferta ou venda de produtos próprios ou de terceiros ao consumidor final; ou III - agente econômicos listados entre as duzentas empresas mais reclamadas no Sistema Nacional de Informações de Defesa do Consumidor da Secretaria Nacional do Consumidor do Ministério da Justiça e Segurança Pública (Sindec), no ano de 2019, nos termos do anexo desta Portaria. $1^{\circ}$ A obrigação de que trata o caput somente se aplica às empresas de que tratam os incisos I a III acima caso elas ou os seus respectivos grupos econômicos: I - tenham faturamento bruto de no mínimo cem milhões de reais no último ano fiscal; II - tenham alcançado uma média mensal igual ou superior a mil reclamações em seus canais de atendimento ao consumidor no último ano fiscal; ou III - sejam reclamados em mais de quinhentos processos judiciais que discutam relações de consumo. $\$ 2^{\circ}$ Mediante prévia provocação do fornecedor interessado, a Coordenação-Geral do Sistema Nacional de Informações de Defesa do Consumidor - CGSINDEC - poderá, a seu critério, dispensá-lo do cadastramento determinado nesta Portaria, em razão do baixo volume das demandas nos Órgãos de Defesa do Consumidor ou quando é verificado que o cadastramento não venha a facilitar a resolução de conflitos com o consumidor" (PORTARIA 15, DE 27 DE MARÇO DE 2020)
} 
respondendo aos consumidores e se esforçando para a solução dos conflitos consumeristas instaurados ${ }^{40}$.

Para responder as reclamações ou solicitações dos consumidores, o fornecedor possui um prazo limite de 10 dias, mas, não há sanção prevista para o fornecedor que ultrapassa este prazo.

Já o consumidor, também tem sua parcela de responsabilidade para a melhora da plataforma, sendo necessário ele se identificar e se comprometer a apresentar todos os dados possíveis que possam auxiliar na solução do conflito instaurado.

Ainda, o consumidor possui a responsabilidade de alimentar o banco de dados da plataforma, haja vista que, após obter a resposta do fornecedor, ele - o consumidor - deve classificar sua reclamação como resolvida ou não resolvida, no prazo de 20 dias, bem como avaliar seu nível de satisfação com a resposta do fornecedor, numa escala entre um e cinco ${ }^{41}$, sendo cinco o nível mais alto de satisfação.

Essas informações e impressões lançadas pelo consumidor formam mais uma ferramenta disponibilizada pela plataforma na sua base pública de dados, a qual faz rankings colocando em evidência quais são os fornecedores que mais se preocupam em adotarem condutas de atenção e consideração em relação aos seus clientes (ora consumidores).

Essa base pode ser de grande auxílio no sentido que permite ao consumidor se informar sobre o fornecedor com quem contratou ou pretende contratar. Ou seja, o consumidor saberá se aquele fornecedor possui muitas reclamações em seu detrimento acerca de os mesmos vícios de um dado produto, por exemplo; bem como, se um dado fornecedor adota, de fato, condutas de colaboração. A base de dados permitirá que o consumidor pesquise sobre as condutas de determinado fornecedores e, assim, ele poderá escolher contratar com aqueles que se mostrem mais dispostos a solucionar eventuais problemas que surgirem com os produtos ou com o serviço prestado.

\footnotetext{
${ }^{40}$ CONSUMIDOR.GOV.BR. Como Aderir - Empresas. (Disponível em: https://www.consumidor.gov.br/pages/conteudo/publico/2 Acesso em 15 dez. 2019). ${ }^{41}$ CONSUMIDOR.GOV.BR. Conheça o Consumidor.gov.br. $\quad$ (Disponível em: https://www.consumidor.gov.br/pages/conteudo/publico/1. Acesso em: 16 dez. 2019).
} 
Vale registrar que a plataforma consumidor.gov.br ainda disponibilizou um questionário relacionado a uma pesquisa de satisfação para ser respondida pelos consumidores que já tivessem utilizado ela, e compreendeu o período entre 2 e 30 de setembro de $2019^{42}$. Neste questionário foi constatado, segundo os dados divulgados pela plataforma, que dentre as 2.030 respostas obtidas $96,6 \%$ declaram recomendar a plataforma.

Os consumidores também demonstraram não saber todas as ferramentas que a plataforma possui, uma vez que 59,2\% das pessoas que responderam ao questionário informaram não saber que a plataforma também está disponível em aplicativo para celular.

Referido dado também pode ser demostrado ao analisar a tabela de reclamações realizadas entre os dias 10/11 e 09/12 do ano de $2019^{43}$, disponível nos dados aberto da plataforma. Na tabela é possível perceber que quase a totalidade das reclamações são efetuadas por meio do Website, seguido por um percentual muito baixo da plataforma Android e depois pelo sistema IOS, conforme gráfico a seguir:

Reclamações realizadas entre 10/11 e 09/12 de 2019

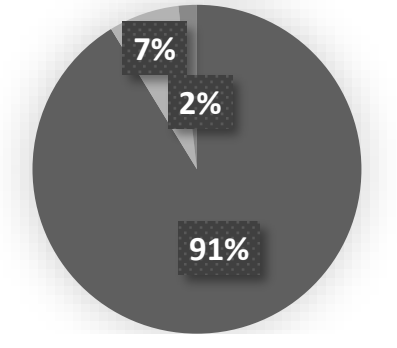

- Website

Aplicativo Android

Aplicativo IOS

Fonte: Dados disponibilizados pela plataforma consumidor.gov.br

\section{O AUXÍliO DA PLATAFORMA CONSUMIDOR.GOV.BR PARA UMA RELAÇÃO DE CONSUMO MAIS HARMÔNICA (ART. $4^{\circ}$ DO CDC).}

A plataforma consumidor.gov.br, criada em 2014, desponta como ferramenta a qual estreita a aproximação entre fornecedor e consumidor de forma mais rápida e menos custosa,

\footnotetext{
${ }^{42}$ CONSUMIDOR.GOV.BR. Indicadores. 
com o intuito de se tentar solucionar, de maneira consensual e desburocratizada, o conflito de consumo, independentemente onde as partes se localizam no território nacional ${ }^{44}$.

Ademais, a medida que o interesse se desperta sobre a plataforma, ela também poderá contribuir para maior transparência na maneira de como o fornecedor lida com os problemas dos seus consumidores, conforme o ranking que ela divulga.

Segundo a pesquisa feita por Tatiane Nunes Viana de Almeida e Anatália Saraiva Martins Ramos, reclamações online's podem, de alguma forma, influenciar na lealdade e na fidelidade dos consumidores a esta ou aquela marca. Ou seja, a reclamação online pode despertar e repercutir num efeito colateral de vantagem que, sendo o fornecedor sensível às reclamações, ele poderá ser mais cuidadoso, bem como adotar condutas anexas de consideração e respeito, além de permitir, quase em tempo real, aperfeiçoar seus produtos e serviços para torná-los, inclusive, mais seguros (art. $6^{\circ}, \mathrm{I}$, do CDC), além de melhor atender as expectativas dos seus consumidores ${ }^{45}$, tanto atuais como os futuros.

Captando essas análises das autoras, as reclamações e situações conflitivas podem subsidiar e contribuir para aperfeiçoar a Política Nacional de Relações de Consumo ${ }^{46}$.

A adoção de mecanismos de autocomposição deve servir para ser mais uma alternativa em benefício do consumidor que busca uma solução que facilite, num primeiro momento, o contato entre consumidor e fornecedor, afinal numa sociedade de massa, os conflitos de consumo se expandem ${ }^{47}$, assim, é importante a valorização do consenso ${ }^{48}$.

\footnotetext{
44“'A principal inovação do Consumidor.gov.br está em possibilitar um contato direto entre consumidores e empresas, em um ambiente totalmente público e transparente, dispensada a intervenção do Poder Público na tratativa individual.”. (CONSUMIDOR.GOV.BR. Conheça o consumidor.gov.br. [Disponível em: https://www.consumidor.gov.br/pages/conteudo/publico/1. Acesso em: 15 ago. 2019].

${ }^{45}$ Nesse sentido: ALMEIDA, Tatiane Nunes Viana de; RAMOS, Anatália Saraiva Martins. Os impactos das reclamações On-line na lealdade dos consumidores: um estudo experimental. Revista de Administração Contemporânea, $\quad$ v. $16, \quad$ n. $\quad 5, \quad$ p. 664-683, 2012. (Disponível em: http://www.scielo.br/scielo.php?script=sci_arttext\&pid=S1415-65552012000500003. Acesso em: 26 out. 2019).

46"“Estas informações potencializam o poder de escolha dos consumidores e contribuem para execução da Política Nacional de Relações de Consumo pelos órgãos do Sistema Nacional de Defesa do Consumidor". CONSUMIDOR.GOV.BR. Conheça o Consumidor.gov.br. (Disponível em: https://www.consumidor.gov.br/pages/conteudo/publico/8. Acesso em: 26out. 2019).

${ }^{47}$ MONTEIRO Filho, Carlos Édison do Rêgo. O problema da massificação das demandas consumeristas: atuação do Procon e proposta de solução à luz do direito contemporâneo. Revista de direito do consumidor, v. 108: 293313 (Nov-Dez/2016), em especial p. 297.

${ }^{48}$ Nesse sentido: “[...] os meios alternativos da solução de conflitos são ágeis, informais, céleres, sigilosos, econômicos e eficazes. Deles é constatado que: são facilmente provocados e, por isso, são ágeis; céleres porque
} 
Esse consenso, segundo Mancuso possui um importante papel, haja vista que a solução negociada torna-se mais célere, menos onerosa, não impactante e tendencialmente, vocacionada para ser cumprida, afinal, os próprios contraditores encontram a solução ${ }^{49}$, dispensando, soluções coercitivamente imposta pelo Estado-Juiz.

Nessa rota, como novo meio alternativo de resolução de conflitos, a plataforma do consumidor.gov.br pode contribuir para estimular soluções mais ágeis e céleres ${ }^{50}$ entre fornecedores e consumidores. O desafio, porém, continua sendo como aperfeiçoar a tutela de consumidores hipervulneráveis os quais demandariam da plataforma alguma proteção especial.

\section{A PLATAFORMA CONSUMIDOR.GOV.BR SOB A PERSPECTIVA DOS TRIBUNAIS ESTADUAIS}

A plataforma consumidor.gov.br ganha espaço e destaque no debate jurídico, como pode ser percebido pela sua atual quantidade de reclamações efetuadas, bem como sua menção nos mais variados Tribunais Estaduais das Unidades Federativas

Desde o lançamento, no dia 27 de junho de 2014, até o dia 20 de abril de 2020, foram cadastrados 1.937 .442 usuários na plataforma e 672 empresas. Esse universo foi responsável por 2.640.896 das reclamações finalizadas, divididas entre as regiões do país, sendo que 3,6\% foram feitas pela região Norte, $16,4 \%$ pela região Nordeste, $10,3 \%$ pela região Centro-Oeste, $49 \%$ pela região Sudeste e $20,7 \%$ pela região $\mathrm{Sul}^{51}$.

Já, acerca da utilização facultativa ou obrigatória da Plataforma, conforme as decisões coletadas junto ao Poder Judiciário, considerando apenas os acórdãos levantados, há situações

rapidamente atingem a solução do conflito; sigilosos porque as manifestações das partes e sua solução são confidenciais; econômicos porque têm baixo custo; eficazes pela certeza da satisfação do conflito" (CAETANO, Luiz Antunes. Arbitragem e Mediação: rudimentos. São Paulo: Atlas, 2002, em especial p.104).

${ }^{49}$ MANCUSO, Rodolfo de Camargo. Acesso à justiça: condicionantes legítimas e ilegítimas. São Paulo, Revista dos Tribunais, 2011.

50“'Aqui, no Consumidor.gov.br, você pode se comunicar diretamente com as empresas participantes, que se comprometem a receber, analisar e responder as reclamações de seus consumidores em até 10 dias”. CONSUMIDOR.GOV.BR. Conheça o consumidor.gov.br. (Disponível em: https://www.consumidor.gov.br/pages/conteudo/publico/1. Acesso em: 10 nov. 2019).

${ }^{51}$ CONSUMIDOR.GOV.BR. Indicadores. Ob cit. 
diversas, mas, reconhecendo, na esmagadora maioria, o caráter facultativo no manuseio dela pelo consumidor. Porém, avançamos para destacar alguns aspectos à medida que se toma contato com o conteúdo das decisões, conforme se verá.

Adotamos como parâmetro na pesquisa, o limite de decisões até 30.10.2019, nos sites dos tribunais Estaduais. Ademais, o filtro de pesquisa utilizado foi constar a expressão “consumidor.gov", ao se selecionar "inteiro teor do acórdão".

Ressalte-se, porém, à medida que procedemos a pesquisa, colacionamos alguns acórdãos de 2020, os quais, embora não computados nos gráficos, destacavam alguma peculiaridade para arguir a relevância da dita plataforma.

No Tribunal de Justiça do Estado de São Paulo, conforme o parâmetro destacado, apontaram-se quatro julgados, mas consideramos apenas três. Dois julgados apontam a iniciativa do consumidor na utilização do consumidor.gov.br, porém, sem êxito, desaguou na referida demanda, tendo sido apenas mais um canal à disposição do consumidor ${ }^{52}$. No terceiro acordão, o apelado-fornecedor argumentou sobre a necessidade de que o consumidor, primeiramente, tente a solução administrativamente, mas o órgão julgador 'a quo' e 'ad quem' não discutiram o tema, dando a entender, salvo melhor juízo que a plataforma é facultativa ${ }^{53}$.

Exclui-se o quarto julgado da análise, haja vista que o litígio não envolve relação de consumo, mas, sim, natureza interempresarial. Destaque-se do acórdão, ao citar a plataforma consumidor.gov.br, que ela simplesmente foi equiparada a um dado site que presta informações sobre viagens. Ou seja, o caso sub judice debatia se uma das partes - um restaurante - teria ou não o direito subjetivo de exigir a exclusão de comentário em seu desfavor lançados por terceiros no site de viagens explorado pela contraparte especializada em informações sobre viagens ${ }^{54}$.

\footnotetext{
${ }^{52}$ TJSP; Agravo de Instrumento 2266878-59.2018.8.26.0000; Relator (a): Daniela Menegatti Milano; $19^{\text {a }}$ Câmara de Direito Privado; Data do Julgamento: 28/04/2014; Data de Registro: 01/03/2019 e TJSP; Apelação Cível 1004274-54.2017.8.26.0564; Relator (a): Alexandre Lazzarini; $9^{a}$ Câmara de Direito Privado; Data do Julgamento: 20/02/2018; Data de Registro: 23/02/2018.

${ }^{53}$ TJSP, Apelação Cível 1007175-29.2016.8.26.0564; Relator (a): Helio Faria, 18a Câmara de Direito Privado; Data do Julgamento: 08/08/2017; Data de Registro: 24/08/2017.

${ }^{54}$ TJSP, Apelação Cível 1104270-30.2015.8.26.0100, Relator (a): Egidio Giacoia, $3^{a}$ Câmara de Direito Privado; Data do Julgamento: 09/10/2018; Data de Registro: 10/10/2018.
} 
Adotando o mesmo filtro, no Tribunal de Justiça de Minas Gerais, três acórdãos são localizados. Num acórdão discutiu indenização em virtude de overbooking, após pleiteada a indenização pelo consumidor, a empresa aérea, em sua defesa, alegou que constava cláusula no contrato que o consumidor antes de buscar qualquer pretensão no âmbito judicial deveria tentar a solução administrativa (PROCON, SENACON, Consumidor.gov, ANAC, etc.) ou a mediação. No entanto, dita cláusula foi repudiada pela Relatora no Tribunal, haja vista que utilizar-se dos meios administrativos para tentar a solução de conflito é uma faculdade do consumidor $^{55}$.

Noutro acórdão, o Ministério Público, ao mover ação civil pública em face de banco, baseou-se na grande quantidade de reclamações feitas pelos consumidores na plataforma consumidor.gov.br.; assim ela contribui para o MP subsidiar-se de dados e informações para demonstrar a verossimilhança de suas alegações ${ }^{56}$; ou seja, a plataforma desempenha uma função social ao ser manejada, com base nas situações ali mencionadas, para a defesa coletiva e difusa dos consumidores que experimentam os mesmos danos.

Recentemente, num julgado do referido tribunal, de 19.2.2020 (não incluído, portanto, nos gráficos deste estudo), extrai-se que nos autos de uma ação que se debatia a inclusão indevida no órgão de proteção ao crédito, o autor pessoa idosa, com mais de 65 anos de idade, recebia benefício previdenciário correspondente a um salário mínimo, porém, ao ser vítima de empréstimo consignado fraudulento teve seu nome inscrito, indevidamente, nos órgãos de proteção ao crédito; o idoso, então, fez pedido de tutela de urgência, mas o Juízo " a quo" a indeferiu sob o lamentável fundamento de que o autor deveria primeiro ter manejado um requerimento administrativo na plataforma consumidor.gov.br. Ante a tal situação, recorreu-se e o Relator, em Agravo de Instrumento, rechaçou tal obrigatoriedade, concedendo a urgência pretendida $^{57}$, confirmando o caráter facultativo pelo consumidor no manejo do sítio consumidor.gov.br, bem como demonstrando que o acesso à justiça pelo consumidor não deve

\footnotetext{
${ }^{55}$ TJMG, Apelação Cível 1.0000.18.144654-3/001, Relator (a): Aparecida Grossi, 17ª Câmara Cível; Data do Julgamento: 03/10/0019; Data da Publicação: 04/10/2019.

${ }^{56}$ Acórdãos referente ao mesmo caso: TJMG, Agravo de Instrumento-Cv 1.0000.17.021376-3/001, Relator (a): Ramom Tácio, $16^{a}$ Câmara Cível, Data do Julgamento: $\quad$ 22/02/2018, Data da Publicação: 23/02/2018; TJMG, Agravo Interno Cv 1.0000.17.021376-3/002, Relator(a): Ramom Tácio , 16ª Câmara Cível. Data do Julgamento:06/10/0017, Data da Publicação: $\quad$ 09/10/2017.

${ }^{57}$ TJMG. Agravo de Instrumento- Cv 1.0000.19.136397-7/001.Rel. Pedro Aleixo, 16a Câm. Cível. Data do julgto.19/2/2020, Data da publicação: 21/2/2020.
} 
ser obstaculizado, ou seja, reconheceu, ainda que de forma oblíqua uma proteção especial ao consumidor hipervulnerável que é o idoso.

No Tribunal do Estado do Rio de Janeiro, foram localizados, a princípio, 11 acórdãos. Nove acórdãos depreendem-se deles que os fornecedores arguiram que, antes do ajuizamento de qualquer medida judicial, o consumidor deve valer-se da plataforma (ou outra forma de reclamação administrativa), porém, no Tribunal, manteve-se a natureza facultativa da utilização dos meios administrativos de solução de conflito pelos consumidores, firmando seus direitos ao amplo acesso à justiça ${ }^{58}$. Noutro, o consumidor valeu-se da reclamação administrativa via plataforma, mas, não sendo resolvida, o conflito foi judicializado ${ }^{59}$.

Destaque-se outro julgado do TJRJ. Discutia-se a possibilidade ou não da prestação de contas em contrato de mútuo; o Relator acolheu o Relatório do juízo ‘a quo'. Neste relatório do juízo 'a quo' constou que o consumidor “não comprovou nenhuma tentativa de solução de seu conflito pelos vários canais disponíveis tais quais, SACs, as agências reguladoras e iniciativas como o consumidor.gov.br do Ministério da Justiça". O Relator não analisou sobre a natureza facultativa ou obrigatória da tutela administrativa antes do ajuizamento da demanda, concentrando sua análise, portanto, na questão de fundo, qual seja, o afastamento da ação de prestação de contas quando ela é movida pelo consumidor-mutuário em detrimento do banco para se debater contrato de mútuo. Depreende-se que o Relator, ao acolher o relatório do juízo ‘a quo', não se é possível concluir que seja ou não favorável ao caráter facultativo da reclamação

\footnotetext{
${ }^{58}$ TJRJ, Agravo De Instrumento0009256-35.2018.8.19.0000, Vigésima Quinta Câmara Cível, Relatora: Isabela Pessanha Chagas, Data de Julgamento: 11/04/2018, Data de Publicação: 12/04/2018; TJRJ Apelação Cível $n^{\circ}$ 0205903-05.2015.8.19.0001, Vigésima Sétima Câmara Cível/Consumidor, Relator: Antonio Carlos dos Santos Bitencourt, Data do Julgamento: 19/07/2017, data da Publicação: 20/07/2017; TJRJ, Apelação Cível No: 003880647.2015.8.19.0205, 26 Câmara Cível / Consumidor Relatora: Natacha Nascimento Gomes Tostes Gonçalves De Oliveira, Data de Julgamento: 22/09/2016, Data de Publicação: 26/09/2016; TJRJ, Apelação Cível No. 0067897 04.2015.8.19.0038, Vigésima Quinta Câmara Cível, Relator: Werson Rêgo, Data de Julgamento: 12/12/2016, Data de Publicação: 13/12/2016; TJRJ, Agravo De Instrumento No 0052164-78.2016.8.19.0000, 24ª Câmara Cível, Relatora: Regina Lucia Passos, Data de Julgamento: 09/11/2016, Data de Publicação: 16/11/2016; TJRJ, Apelação Cível no 0024084-87.2016.8.19.0038, Vigésima Quinta Câmara Cível, Relator: Isabela Pessanha Chagas, Data de Julgamento: 19/10/2016, Data de Publicação: 21/10/2016; TJRJ, Apelação N. 0084000-86.2015.8.19.0038, 26ª Câmara Cível / Consumidor Relatora: Natacha Nascimento Gomes Tostes Gonçalves De Oliveira, Data do Julgamento: 29/09/2016 - Data de Publicação: 03/10/2016; Ap. Cív. 0074592-71.2015.8.19.0038. Rel. Des. Sandra

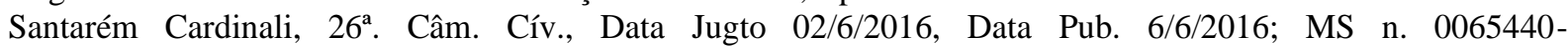
79.2016.8.19.0000. Rel. Cintia Santarém Cardinali. 24 ${ }^{\mathrm{a}}$ Câm. Cív. Rela. Cintia Santarém Cardineali. Data julgamento 15/2/2017; Data da Pub. 17/2/2017.

${ }^{59}$ TJRJ, Apelação Cível no 0307541-81.2015.8.19.0001, Vigésima Sexta Câmara Cível Consumidor, Relatora: Denise Nicoll Simões, Data de Julgamento: 09/02/2017, Data de Publicação: 13/02/2017.
} 
administrativa prévia ${ }^{60}$, mas, sugere-se, a princípio, por dedução, que sim, seja favorável à facultatividade da plataforma, afinal, superou esse ponto, avançando e decidindo a questão de fundo da dita ação.

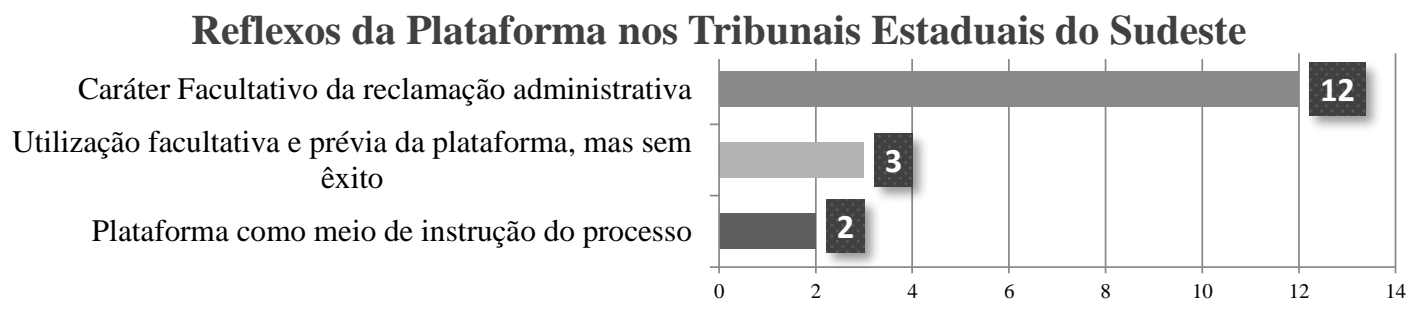

Ainda, sublinhe-se o acórdão do TJRJ, tirado do MS n. 0065440-79.2016.8.19.0000 Rel. Cintia Santarém Cardinali, cuja autoridade impetrada foi o Juízo 'a quo’ (Comarca de Nova Iguaçu), nos autos da ação declaratória de inexistência de relação jurídica e débitos c/c indenização e tutela antecipada proposta em face de um dado banco. Dita autoridade jurisdicional impetrada obstou o andamento do feito, ante a ausência de tentativa prévia de solução por meios administrativos; porém, foi reconhecido direito líquido e certo ao consumidor-impetrante de acesso à jurisdição independentemente de haver ou não prévia tentativa de solução administrativa (por exemplo, o sítio consumidor.gov.br, Bacen).

No Tribunal de Justiça do Espírito Santo, com o parâmetro “consumidor.gov” nenhum julgado foi localizado.

No que concerne à região Sul, o Tribunal Estadual do Rio Grande do Sul teve expressivo resultado. Foram localizados 46 acórdãos a partir do parâmetro "consumidor.gov". 33 acórdãos destacam que os consumidores tinham manejado previamente a plataforma, mas, sem solução, ocorreu a judicialização dos $\operatorname{conflitos}^{61}$. Por outro lado, nove acórdãos destacaram

\footnotetext{
${ }^{60}$ TJRJ, Ap. Civ.n 0070348-02.2015.8.19.0038, Vigésima Quinta Câmara Cível, Relator: Desembargador Werson Rêgo, Data do Julgamento: 31/08/2016, Data da Publicação: 02/09/2016.

${ }^{61}$ TJRS, Apelação Cível, No 70081844219, Décima Segunda Câmara Cível, Relator: Umberto Guaspari Sudbrack, Data de Julgamento: 26/09/2019; TJRS, Apelação Cível, Nº 70082701467, Décima Sétima Câmara Cível, Relator: Paulo Sérgio Scarparo, Data do Julgamento: 26/09/2019; TJRS, Apelação Cível, No 70082562760, Décima Segunda Câmara Cível, Relator: Umberto Guaspari Sudbrack, Data do Julgamento: 17/09/2019; TJRS, Apelação Cível, $N^{\circ}$ 70082113846, Décima Segunda Câmara Cível, Relator: Umberto Guaspari Sudbrack, Data do Julgamento: 29/08/2019; TJRS, Recurso Cível, No 71008690232, Primeira Turma Recursal Cível, Relator: Fabiana Zilles, Data do Julgamento: 23/07/2019; TJRS, Recurso Cível, No 71008737223, Primeira Turma Recursal Cível, Relator: Fabiana Zilles, Data do Julgamento: 23/07/2019; TJRS, Recurso Cível, No 71008361123, Quarta Turma Recursal Cível, Relator: Luis Antonio Behrensdorf Gomes da Silva, Data do Julgamento: 26/04/2019; TJRS,
} 
a obrigatoriedade de se tentar, extrajudicialmente, a solução de conflito de forma prévia ao ajuizamento da ação ${ }^{62}$. Por derradeiro, há quatro acórdãos nos quais os fornecedores alegaram necessidade de os consumidores tentarem usar canais institucionais extrajudiciais antes de ajuizarem a demanda, como PROCONS e a plataforma em questão, mas sequer foi levantado

Apelação Cível, No 70079962759, Nona Câmara Cível, Relator: Carlos Eduardo Richinitti, Data do Julgamento: 27/03/2019; TJRS, Recurso Cível, № 71007707482, Segunda Turma Recursal Cível, Relator: Alexandre de Souza Costa Pacheco, Data do Julgamento: 14/11/2018; TJRS, Apelação Cível, No 70078644234, Décima Primeira Câmara Cível, Relator: Antônio Maria Rodrigues de Freitas Iserhard, Data do Julgamento: 07/11/2018; TJRS, Recurso Cível, No 71007505811, Segunda Turma Recursal Cível, Relator: Elaine Maria Canto da Fonseca, Data do Julgamento: 18/07/2018; TJRS, Recurso Cível, No 71007390578, Quarta Turma Recursal Cível, Relator: Luis Antonio Behrensdorf Gomes da Silva, Data do Julgamento: 23/02/2018; TJRS, Agravo de Instrumento, N $^{\circ}$ 70075342790, Décima Sétima Câmara Cível, Relator: Marta Borges Ortiz, Data do Julgamento: 14/12/2017; TJRS, Recurso Cível, No 71007341282, Segunda Turma Recursal Cível, Relator: Ana Cláudia Cachapuz Silva Raabe, Data do Julgamento: 13/12/2017; TJRS, Recurso Cível, Nº 71007293905, Segunda Turma Recursal Cível, Relator: Ana Cláudia Cachapuz Silva Raabe, Data do Julgamento: 13/12/2017; TJRS, Recurso Cível, No 71007259898, Segunda Turma Recursal Cível, Relator: Ana Cláudia Cachapuz Silva Raabe, Data do Julgamento: 22/11/2017; TJRS, Recurso Cível, No 71006975460, Quarta Turma Recursal Cível, Relator: Gisele Anne Vieira de Azambuja, Data do Julgamento: 17/08/2017; TJRS, Recurso Cível, № 71007141112, Quarta Turma Recursal Cível, Relator: Gisele Anne Vieira de Azambuja, Data do Julgamento: 20/10/2017; TJRS, Recurso Cível, No 71006976153, Quarta Turma Recursal Cível, Relator: Gisele Anne Vieira de Azambuja, Data de Julgamento: 17/08/2017; TJRS, Recurso Cível, No 71007034887, Quarta Turma Recursal Cível, Relator: Gisele Anne Vieira de Azambuja, Data do Julgamento: 17/08/2017; TJRS, Recurso Cível, No 71006976484, Quarta Turma Recursal Cível, Relator: Gisele Anne Vieira de Azambuja, Data do Julgamento: 17/08/2017; TJRS, Recurso Cível, No 71006910996, Quarta Turma Recursal Cível, Relator: Gisele Anne Vieira de Azambuja, Data do Julgamento: 13/07/2017; TJRS, Recurso Cível, No 71006950208, Quarta Turma Recursal Cível, Relator: Gisele Anne Vieira de Azambuja, Data do Julgamento: 13/07/2017; TJRS, Agravo de Instrumento, No 70072309149, Vigésima Terceira Câmara Cível, Relator: Clademir José Ceolin Missaggia, Data do Julgamento: 28/03/2017; TJRS, Recurso Cível, No 71006394993, Quarta Turma Recursal Cível, Relator: Glaucia Dipp Dreher, Data do Julgamento: 16/12/2016; TJRS, Agravo de Instrumento, No 70071448179, Décima Terceira Câmara Cível, Relator: Elisabete Correa Hoeveler, Data do Julgamento: 15/12/2016; TJRS, Recurso Cível, N $^{\circ} 71006376347$, Quarta Turma Recursal Cível, Relator: Glaucia Dipp Dreher, Data do Julgamento: 11/11/2016; ${ }^{61}$ TJRS, Apelação Cível, No 70080879273, Nona Câmara Cível, Relator: Tasso Caubi Soares Delabary, Data do Julgamento: 12/06/2019; TJRS, Recurso Cível; No 71008224081, Quarta Turma Recursal Cível, Relator: Silvia Maria Pires Tedesco, Data do Julgamento: 26/04/2019; TJRS, Recurso Cível; No 71008308165, Quarta Turma Recursal Cível, Relator: Luis Antonio Behrensdorf Gomes da Silva, Data do Julgamento: 26/04/2019; TJRS, Recurso Cível; No 71008220048, Quarta Turma Recursal Cível, Relator: Luis Antonio Behrensdorf Gomes da Silva, Data do Julgamento: 29/03/2019;TJRS, Recurso Cível, N 71006492979, Quarta Turma Recursal Cível, Relator: Glaucia DippDreher, Data do Julgamento: 07/02/2017; TJRS, Recurso Cível, No 71008638751, Quarta Turma Recursal Cível, Relator: Gisele Anne Vieira de Azambuja, Data do Julgamento: 28/06/2019.

${ }^{62}$ TJRS, Apelação Cível, N ${ }^{\circ} 70075424515$, Nona Câmara Cível, Relator: Tasso Caubi Soares Delabary, Data do Julgamento: 28/02/2018; TJRS, Agravo, № 70068520840, Nona Câmara Cível, Relator: Miguel Ângelo da Silva, Data do Julgamento: 16/03/2016; TJRS, Agravo Regimental, No 70068574656, Nona Câmara Cível, Relator: Miguel Ângelo da Silva, Data do Julgamento: 16/03/2016; TJRS, Agravo, No 70068560358, Nona Câmara Cível, Relator: Miguel Ângelo da Silva, Data do Julgamento: 16/03/2016; TJRS, Agravo, № 70067840710, Nona Câmara Cível, Relator: Miguel Ângelo da Silva, Data do Julgamento: 16/03/2016; TJRS, Agravo de Instrumento, No 70068066216, Nona Câmara Cível, Relator: Carlos Eduardo Richinitti, Data do Julgamento: 16/03/2016, TJRS, Agravo, $N^{\circ} 70068056530$, Nona Câmara Cível, Relator: Miguel Ângelo da Silva, Data do Julgamento: 16/03/2016; TJRS, Agravo Regimental, No 70068379965, Nona Câmara Cível, Relator: Eugênio Facchini Neto, Data do Julgamento: 15/03/2016; TJRS, Agravo de Instrumento, № 70068119684, Nona Câmara Cível,Relator: Carlos Eduardo Richinitti, Data do Julgamento: 16/03/2016. 
debate no acórdão, o que revela a natureza facultativa dos meios administrativos para os consumidores tentarem alguma solução dos conflitos de consumo ${ }^{63}$.

No Tribunal de Justiça do Paraná, utilizando-se do mesmo parâmetro (e a data 30.10.2019), foram apontadas onze decisões. Sete destacam que o consumidor, embora tenha utilizado previamente a plataforma, a autocomposição não prosperou, não evitando a judicialização dos conflitos ${ }^{64}$. Outro acórdão destaca que o consumidor utilizou a plataforma consumidor.gov.br para solicitar extratos de sua conta corrente e o fornecedor adotou deveres de colaboração fornecendo-os, o que demonstra a utilidade da plataforma como uma ferramenta de auxílio ao consumidor para entrar em contato com o fornecedor e obter, de maneira mais rápida e prática, documentos necessários; e posteriormente, o consumidor usou ditos documentos para instruir medida judicial de repetição do indébito e anulação do contrato bancário em face do agente financeiro ${ }^{65}$.

Noutro acórdão, o juiz 'a quo' entendeu pela necessidade de que o consumidor, primeiramente, tente a solução administrativa, mas o órgão 'ad quem' reconheceu a facultatividade da plataforma, vez que o acesso ao Judiciário é amplo e assegurado ${ }^{66}$. Numa outra decisão, a facultatividade também foi reconhecida, sendo que nesta, a tal situação foi reconhecida em primeiro grau, e confirmada pelo Tribunal ${ }^{67}$.

Vale ressaltar uma decisão em que o órgão julgador entendeu que o consumidor, por não utilizar nenhum canal administrativo para tentar solucionar o problema, como ANATEL,

\footnotetext{
${ }^{63}$ TJRS, (excluir) Apelação Cível, № 70079080453, Vigésima Câmara Cível, Relator: Glênio José Wasserstein Hekman, Data do Julgamento: 17/10/2018; TJRS, Apelação Cível, No 70078415262, Décima Câmara Cível, Relator: Marcelo Cezar Muller, Data do Julgamento: 30/08/2018; TJRS, Apelação Cível, No 70073918211, Vigésima Quarta Câmara Cível, Relator: Altair de Lemos Junior, Data do Julgamento: 28/06/2017; TJRS, Mandado de Segurança, N ${ }^{\circ} 71006852974$, Segunda Turma Recursal Cível, Relator: Elaine Maria Canto da Fonseca, Data do Julgamento: 29/08/2017.

${ }^{64}$ TJPR, $3^{\mathrm{a}}$ Turma Recursal, 0001344-05.2018. 8.16.0118, Rel.: Marco Vinícius Schiebel, Data Julgamento: 23/10/2019; TJPR, $3^{\text {a }}$ Turma Recursal, 0004854-54.2018.8.16.0044, Rel.: Juiz Marco Vinícius Schiebel, Data Julgamento: 27/05/2019; TJPR, $3^{\text {a }}$ Turma Recursal, 0000320-19.2016.8.16.0018, Rel.: Juíza Fernanda de Quadros Jorgensen Geronasso, Data do Julgamento: 27/05/2019; TJPR, 8 a C. Cível, 0005180-24.2017.8.16.0052, Rel.: Desembargador Marco Antonio Antoniassi, Data Julgamento: 25/04/2019; TJPR, $3^{\text {a }}$ Turma Recursal, 000131003.2018.8.16.0127, Rel.: Juíza Fernanda de Quadros Jorgensen Geronasso, Data do Julgamento: 27/03/2019; TJPR, $3^{\text {a } T u r m a ~ R e c u r s a l, ~ 0001314-40.2018 .8 .16 .0127, ~ R e l .: ~ J u i ́ z a ~ F e r n a n d a ~ d e ~ Q u a d r o s ~ J o r g e n s e n ~ G e r o n a s s o, ~}$

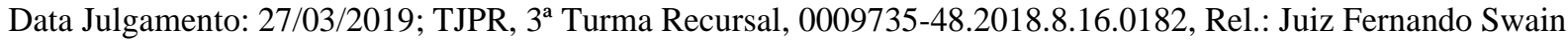
Ganem, Data de Julgamento: 27/03/2019.

${ }^{65}$ TJPR, 2 $2^{\text {a }}$ Turma Recursal, 0020218-81.2017.8.16.0018, Rel.: Luciano Lara Zequinão, Data do Julgamento: $18 / 10 / 2019$.

${ }^{66}$ TJPR, $3{ }^{\text {a }}$ Turma Recursal, 0001372-65.2019.8.16.9000, Rel.: Juiz Leo Henrique Furtado Araújo 03/10/2019.

${ }^{67}$ TJPR, $2^{\text {a }}$ Turma Recursal, 0000029-09.2016.8.16.0086, Rel.: Juiz Siderlei Ostrufka Cordeiro, Data Julgamento: $18 / 04 / 2017$.
} 
Call Center ou consumidor.gov.br, não experimentou nem dissabor e nem dano, assim, não haveria o que indenizá-1o ${ }^{68}$. Depreende-se, salvo melhor juízo, que nesse julgado sugere o caráter obrigatório da tentativa de solução prévia dos canais administrativos, para evitar demanda judicial, vez que, ditos canais administrativos podem e devem ser usados como alternativas para o consumidor obter o desejado.

Em Santa Catarina 23 acórdãos mencionaram a dita plataforma, sendo que oito destacam o caráter facultativo dela ${ }^{69}$. Já para outros três, o consumidor deve, previamente, à demanda judicial, submeter sua reclamação perante a plataforma, para demonstrar o intuito de, primeiramente, esgotar os meios alternativos à sua disposição ${ }^{70}$.

Doze julgados do dito tribunal destacaram a tentativa de solução pelo consumidor utilizando-se da plataforma que restou infrutífera ${ }^{71}$.

\footnotetext{
${ }^{68}$ TJPR, $3^{\mathrm{a}}$ Turma Recursal, 0001018-71.2019.8.16.0098, Rel.: Juíza Fernanda de Quadros Jorgensen Geronasso, Data do Julgamento: 04/10/2019.

${ }^{69}$ TJSC, Apelação Cível n. 0301229-65.2017.8.24.0103, rel. Saul Steil, Terceira Câmara de Direito Civil, Data do Julgamento: 15/10/2019; TJSC, Agravo Regimental n. 4000048-72.2018.8.24.9003, rel. André Milani, Terceira Turma de Recursos, Data do Julgamento: 21/09/2018; TJSC, MS n. 4000044-35.2018.8.24.9003, rel. Maira Salete Meneghetti, Terceira Turma de Recursos, Data do Julgamento: 31/08/2018; TJSC, Apelação Cível n. 030100768.2016.8.24.0027, rel. Jânio Machado, Quinta Câmara de Direito /Comercial, Data do Julgamento: 20/11/2017; TJSC, Apelação Cível n. 0301006-83.2016.8.24.0027, rel. Cláudio Valdyr Helfenstein, Quinta Câmara de Direito Comercial, Data do Julgamento: 22/06/2017;Apelação Cível n. 0302108-69.2015.8.24.0062, rel. Marcus Tulio Sartorato, Terceira Câmara de Direito Civil, Data do Julgamento: 27/08/2019; TJSC, Apelação Cível n. 030102848.2016.8.24.0058, rel. Selso de Oliveira, Quarta Câmara de Direito Civil, Data do Julgamento: 13/05/2019; TJSC, Apelação n. 0300525-24.2015.8.24.0135, rel. José Carlos Carstens Köhler, Quarta Câmara de Direito Comercial, Data do Julgamento: 19/07/2016.

${ }^{70}$ TJSC, Agravo n. 4016897-02.2017.8.24.0000, rel. Hildemar Meneguzzi de Carvalho, Câmara Civil Especial, Data do Julgamento: 24/05/2018, TJSC, RI n. 0301722-91.2017.8.24.0022, rel. Sílvio Dagoberto Orsatto, Sexta Turma de Recursos, Data do Julgamento: 28/09/2017; TJSC, Apelação Cível n. 0306003-62.2016.8.24.0075, rel. Jânio Machado, Quinta Câmara de Direito Comercial, Data do Julgamento: 08/05/2017.

${ }^{71}$ TJSC, Apelação Cível n. 0300477-59.2018.8.24.0103, rel. Carlos Roberto da Silva, Sétima Câmara de Direito Civil, Data do Julgamento: 12/09/2019; TJSC, Apelação Cível n. 0305864-20.2016.8.24.0008, rel. Luiz Cézar Medeiros, Quinta Câmara de Direito Civil, Data do Julgamento: 11/09/2019; TJSC, Apelação Cível n. 031561045.2018.8.24.0038, rel. Luiz Cézar Medeiros, Quinta Câmara de Direito Civil, Data do Julgamento: 10/07/2019; TJSC, Apelação Cível n. 0310146-71.2017.8.24.0039, rel. André Carvalho, Sexta Câmara de Direito Civil, Data do Julgamento: 28/05/2019; TJSC, Apelação Cível n. 0304871-19.2017.8.24.0015, rel. Rubens Schulz, Segunda Câmara de Direito Civil, Data do Julgamento: 21/02/2019; TJSC, Apelação Cível n. 0300064-19.2018.8.24.0015, rel. Rubens Schulz, Segunda Câmara de Direito Civil, Data do Julgamento: 21/02/2019; TJSC, Agravo de Instrumento n. 4019234-61.2017.8.24.0000, rel. Soraya Nunes Lins, Quinta Câmara de Direito Comercial, Data do Julgamento: 14/02/2019; TJSC, Apelação Cível n. 0300191-18.2018.8.24.0027, rel. Ricardo Fontes, Quinta Câmara de Direito Civil, Data do Julgamento: 12/12/2018; TJSC, Agravo de Instrumento n. 400194836.2018.8.24.0000, rel. Jânio Machado, Quinta Câmara de Direito Comercial, Data do Julgamento: 14/12/2018; TJSC, Apelação Cível n. 0300501-23.2018.8.24.0092, rel. Jânio Machado, Quinta Câmara de Direito Comercial, Data do Julgamento: 03/12/2018; TJSC, Recurso Inominado n. 0300973-25.2017.8.24.0103, rel. Luís Paulo Dal Pont Lodetti, Quinta Turma de Recursos, Data do Julgamento: 24/04/2019; TJSC, Apelação Cível n. 030447724.2017.8.24.0011, rel. Fernando Carioni, Terceira Câmara de Direito Civil, Data do Julgamento: 15/03/2018.
} 


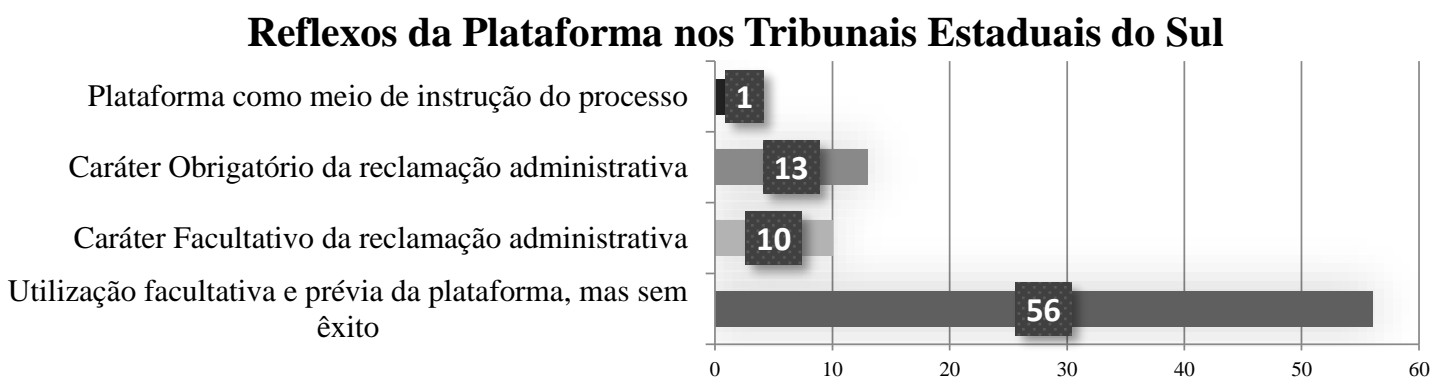

No Nordeste do País, a Bahia apresenta quatro acórdãos ao pesquisar consumidor.gov'. Num dos acórdãos destaca-se a utilização da plataforma pelo consumidor como prova de sua solicitação ${ }^{72}$, demonstrando que ela contribui para ampliar a proteção do consumidor, pois ao manejá-la e não ter resposta do fornecedor, resta configurada a falta de colaboração deste para solucionar o problema do consumidor. Mas não se avalia a obrigatoriedade da plataforma, em que pese fixamos o entendimento do caráter facultativo dela. Na verdade, o que se depreende é que, à medida que o fornecedor não se esforça para solucionar o problema do consumidor, sua situação de vulnerabilidade pode se acentuar, caso o produto ou serviço com problema possa ser classificado como essencial.

Outro julgado, igualmente interessante, associou a inércia do fornecedor à teoria do desvio produtivo ou perda do tempo útil ${ }^{73}$. Isto é, o consumidor recorreu à plataforma consumidor.gov.br, mas o fornecedor não adotou deveres de colaboração para solução do problema com brevidade, o que fez com que o consumidor desperdiçasse seu tempo útil propondo uma demanda judicial para solucionar algo que já poderia ter sido resolvido amigavelmente, nesse sentido, em razão de sua inércia, o fornecedor foi condenado em valores indenizatórios ${ }^{74}$; ou seja, referida decisão, ressalta a importância da plataforma na defesa dos direitos e garantias do consumidor, associando-a como ferramenta para se evitar o desperdício do tempo útil do consumidor.

\footnotetext{
${ }^{72}$ TJBA, Recurso Inominado, No: 0003593-29.2017.8.05.0001, Relator (a): Karla Kristiany Moreno De Oliveira, Data do Julgamento: 02/08/2017.

${ }^{73}$ DESSAUNE, Marcos. Teoria aprofundada do desvio produtivo do consumidor: o prejuízo do tempo desperdiçado e da vida alterada. $2^{\text {a }}$ Ed. Edição especial do Autor, 2017.

${ }^{74}$ TJBA, Recurso Inominado, N ${ }^{\circ}$ : 0051894-07.2017.8.05.0001, Relator (a): Nicia Olga Andrade De Souza Dantas, Data do Julgamento: 24/01/2018.
} 
Noutra, o julgado aponta que o fornecedor alegou que o consumidor não utilizou os canais administrativos (como consumidor.gov.br, Centrais de atendimentos, Agência), mas nem sequer foi analisado tal ponto, depreendendo-se que a utilização prévia destes canais é facultativo, sendo apenas mais uma alternativa dada ao consumidor para resolver suas atribulações ${ }^{75}$.

Finalmente, o quarto julgado do tribunal baiano repudiou a pretensão do consumidor a título de danos morais pela inexistência de qualquer dor ou sofrimento. Destaca a decisão que o consumidor não se valeu de solicitação administrativa para tentar solucionar seu problema, não demonstrando, assim, um efetivo desgaste para ver sua pretensão acolhida; é possível, salvo melhor juízo, depreender que a utilização da plataforma é obrigatória para demonstrar o dissabor experimentado, embora o julgado não reconheça expressamente o caráter $^{76}$. Sem estender o debate, a decisão acolhe o sentido de dano moral indenizável sob a perspectiva subjetiva; porém, sendo o direito do consumidor um direito humano, a melhor alternativa é compreender o sentido objetivo de dano, enquanto violação de algum dos atributos da sua situação existencial.

Em Pernambuco, na data base apontada em nossa pesquisa, identificamos, ressalvada alguma falha no manejo do site do tribunal pelos autores, apenas, um julgado. Nela, o fornecedor alegou a não utilização, previamente à ação judicial, da plataforma pelo consumidor, mas tal aspecto nem foi analisado, demonstrando, salvo melhor juízo, que o manejo da plataforma consumidor.gov.br é facultativo ${ }^{77}$. No Ceará também consta um julgado, o qual destaca a não obrigatoriedade da utilização prévia da plataforma pelo consumidor ${ }^{78}$.

Já no Piauí, Rio Grande do Norte, Paraíba, Alagoas, Maranhão e Sergipe não foi encontrado nenhum acordão que tivesse em seu teor "consumidor.gov".

\footnotetext{
${ }^{75}$ TJBA, Recurso Inominado, No: 0073477-14.2018.8.05.0001, Relator (a): Cristiane Menezes Santos Barreto, Data do Julgamento: 19/06/2019.

${ }^{76}$ TJBA, Recurso Inominado, No: 0072002-23.2018.8.05.0001, Relator (a): Cristiane Menezes Santos Barreto, Data do Julgamento: 10/07/2019.

${ }^{77}$ TJPE, Recurso Inominado, $\mathrm{n}^{\circ}$ 0001492-90.2015.8.17.8234, Relator (a): Maria do Perpetuo Socorro de Britto Alves, Data do Julgamento: 06/06/2017.

${ }^{78}$ TJCE, Apelação: 0010959-54.2015.8.06.0101 Relator (a): Maria De Fátima De Melo Loureiro; Comarca: Itapipoca; Órgão julgador: $1^{\text {a }}$ Vara, Data do julgamento: 09/10/2019; Data de registro: 09/10/2019.
} 


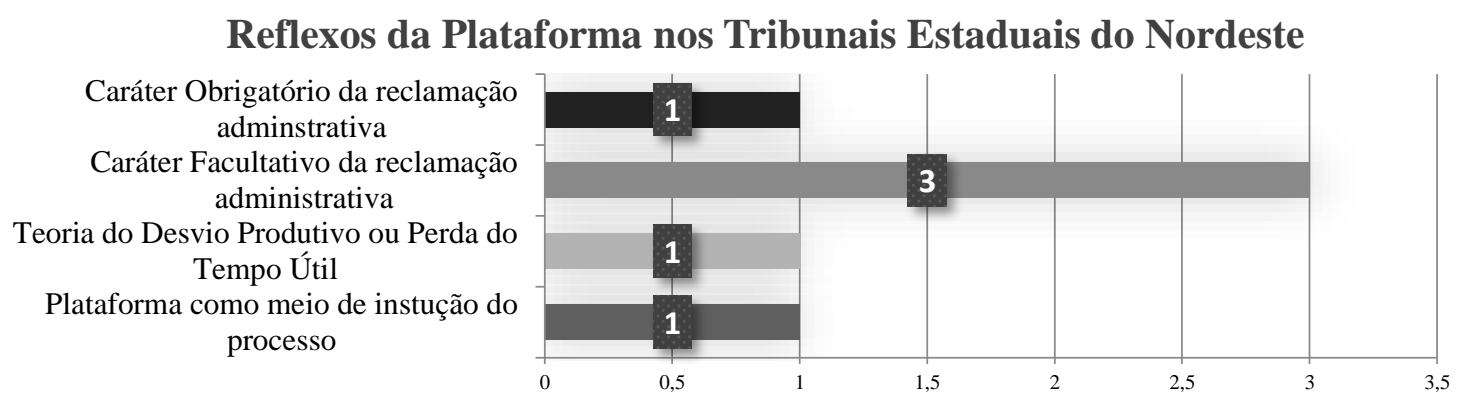

No que diz respeito a região norte, o Acre, Amazonas, Roraima, Amapá e Pará não foram localizados acórdãos com o parâmetro "consumidor.gov".

Já, Tocantins, também da Região Norte, possui 10 acórdãos com base no parâmetro em questão. Oito destacam que previamente à demanda judicial, o consumidor recorreu à plataforma, mas não obteve êxito ${ }^{79}$; já outro acórdão destacou o manejo da plataforma, mas o consumidor desistiu dela durante o procedimento ${ }^{80}$; finalmente, o outro acórdão, apenas realçou a plataforma como mais um meio alternativo disponível ao consumidor, sendo um instrumento que contribuiu para garantir e ampliar a tutela dos direitos do destinatário final. O que merece destaque do julgado é que o julgador considerou a facilidade na utilização da plataforma, já que ela pode ser manejada pelo consumidor valendo-se, tão somente, de um equipamento móvel ${ }^{81}$. Realçamos, no entanto, que a simples facilidade do acesso aos canais de reclamações disponíveis ao consumidor não atenua a situação de vulnerabilidade do consumidor, principalmente, se ele é analfabeto ou superendividado.

\footnotetext{
${ }^{79}$ TJTO Apelação Cível No 0001948-23.2018.827.0000, Relator: Jocy Gomes de Almeida, $1^{\text {a }}$ Câmara Cível, Data do Julgamento: 18/07/2019; TJTO Apelação Cível No 0009303-84.2018.827.0000, $1^{\text {a }}$ Câmara Cível, Relatora: Maysa Vendramini Rosal, Data do Julgamento: 27/06/2018, TJTO Apelação Cível No 0001490-06.2018.827.0000, Relator: Gilson Coelho Valadares, $1^{\text {a }}$ Câmara Cível, Data do Julgamento: 20/03/2019; TJTO Apelação Cível No . 0006462-19.2018.827.0000, Relator: Jacqueline Adorno, $1^{\text {a }}$ Câmara Cível, Data do Julgamento: 28/05/2018, TJTO Apelação Cível No . 0008604-93.2018.827.0000, Relator: Jacqueline Adorno, $1^{\text {a }}$ Câmara Cível, Data do Julgamento: 15/05/2018, TJTO Agravo de Instrumento $\mathrm{N}^{\circ}$ 0026483-16.2018.827.0000, Relator: Moura Filho, Data do Julgamento:11/03/2019, Agravo de Instrumento $\mathrm{N}^{\circ}$ 0011061-98.2018.827.0000, Relatora: Edilene Pereira de Amorim Alfaix Natário, Data do Julgamento: 19/11/2018; RI no 0024400-09.2017.827.9200, Relator Juiz Arióstenis Guimarães Vieira, Data do Julgamento: 13/06/2018.

${ }^{80} \mathrm{TJTO}$ Rec. I n ${ }^{\circ}$ 0024442-58.2017.827.9200, Relator: Juiz Arióstenis Guimarães Vieira, Data do Julgamento: 03/10/2018.

${ }^{81}$ TJTO RI $n^{\circ}$ 0024013-91.2017.827.9200, Relator Juiz Arióstenis Guimarães Vieira, Data do Julgamento: $13 / 06 / 2018$
} 
Em Rondônia dois acórdãos se destacaram na pesquisa. Em ambos, os julgadores defendem o caráter facultativo do manejo da plataforma pelos consumidores ${ }^{82}$.

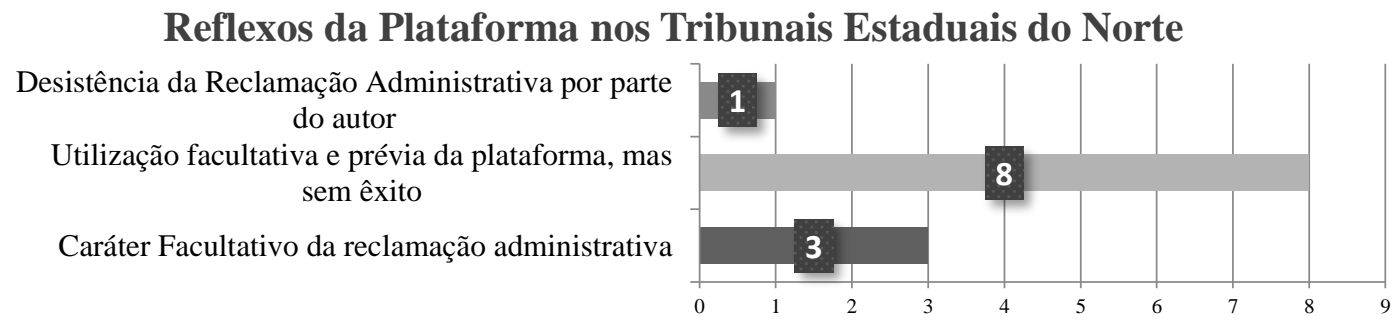

No Centro-Oeste, o impacto da plataforma se mostrou bem mais evidente. No Mato Grosso do Sul foram encontrados mais de 100 acórdãos. Optou-se, então, uma amostragem; assim, o critério de busca foi filtrado ainda mais para que a expressão "consumidor.gov" constasse nas ementas dos acórdãos e, dentre os selecionados, os dez mais recentes até 30.10.2019. Todos os dez acórdãos reconheceram que é facultativo ao consumidor a utilização da plataforma consumidor.gov.br. Uma consideração, no entanto, merece destacar da leitura dos ditos julgados colacionados. Em todos eles, o juízo a quo, ao receber a inicial, determinou que o consumidor deveria comprovar a tentativa de solução administrativa e, não ocorrendo, o feito era sentenciado. Interposto o recurso, os julgadores decidiram pelo caráter facultativo da utilização da plataforma e, por conseguinte, o retorno dos processos à vara de origem para o regular andamento deles ${ }^{83}$.

\footnotetext{
${ }^{82}$ TJRO Apelação, no 7002147-92.2017.822.0001, $2^{\text {a }}$ Câmara Cível, Relator (a): Isaias Fonseca Moraes, Data de julgamento: 26/02/2019, TJRO Apelação, $n^{\circ}$ 7065074-31.2016.822.0001, 2 ${ }^{\mathrm{a}}$ Câmara Cível, Relator (a): Kiyochi Mori., Data do Julgamento: 08/06/2018.

${ }^{83}$ TJMS. Apelação Cível n. 0804277-38.2018.8.12.0017, $4^{\text {a }}$ Câmara Cível, Relator (a): Alexandre Bastos, Data do Julgamento: 23/10/2019, Data da Publicação: 25/10/2019; TJMS. Apelação Cível n. 0800673-35.2019.8.12.0017, $2^{a}$ Câmara Cível, Relator (a): Marco André Nogueira Hanson, Data do Julgamento: 18/10/2019, Data da Publicação: 22/10/2019; TJMS. Apelação Cível n. 0800232-46.2019.8.12.0052, 2a Câmara Cível, Relator (a): Marco André Nogueira Hanson, Data do Julgamento: 18/10/2019, Data da Publicação: 22/10/2019; TJMS. Apelação Cível n. 0804420-27.2018.8.12.0017, $1^{\text {a }}$ Câmara Cível, Relator: João Maria Lós, Data do Julgamento: 14/10/2019, Data da Publicação: 17/10/2019; TJMS. Apelação Cível n. 0801109-09.2019.8.12.0012, $1^{\text {a }}$ Câmara Cível, Relator (a): João Maria Lós, Data do Julgamento: 14/10/2019, Data da Publicação: 16/10/2019; Ap. Cív. 0800353-64.2019.8.12.00232, Rel. Dorival Renato Pavan, $3^{\mathrm{a}}$ Câm. Civ., Data julgamento: 30/10/2019; TJMS.

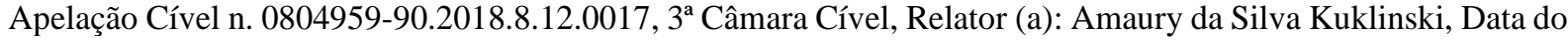
Julgamento: 25/10/2019, Data da Publicação: 29/10/2019; TJMS. Apelação Cível n. 0804750-24.2018.8.12.0017, $3^{a}$ Câmara Cível, Relator (a): Amaury da Silva Kuklinski, Data do Julgamento: 25/10/2019, Data da Publicação: 29/10/2019; TJMS. Apelação Cível n. 0800215-10.2019.8.12.0052, $3^{\text {a }}$ Câmara Cível, Relator (a): Amaury da Silva Kuklinski, Data do Julgamento: 25/10/2019, Data da Publicação: 29/10/2019; TJMS. Apelação Cível n. 0800443-90.2019.8.12.0017, $3^{\text {a }}$ Câmara Cível, Relator (a): Amaury da Silva Kuklinski, Data do Julgamento: 25/10/2019, Data da Publicação: 29/10/2019;
} 
Já, no Distrito Federal, foram encontrados três acórdãos. Num, a reclamação feita administrativamente, por meio da plataforma, foi a razão determinante para justificar a procedência do pedido de danos morais, subentendendo-se, salvo melhor juízo, o caráter obrigatório da tentativa prévia do meio administrativo, bem como evidenciando, mais uma vez, a importância da utilização da plataforma como prova do desgaste moral ocasionado pelo fornecedor quando este não busca resolver, de pronto, as pretensões do consumidor ${ }^{84}$. Noutro, foi considerada a cláusula no contrato entre fornecedor e consumidor como nula haja vista que ela estabelecia que deveria se tentar, num primeiro momento, a solução administrativa do conflito $^{85}$, realçando a facultatividade da tentativa de solução extrajudicial; finalmente, outro julgado destacou que, embora o consumidor tivesse tentado a solução administrativa, restou frustrada, culminando com o ajuizamento da ação judicial ${ }^{86}$.

Em Goiás e no Estado do Mato grosso não foram localizados resultados que contivessem a expressão "consumidor.gov".

\section{Reflexos da Plataforma nos Tribunais Estaduais do Centro-Oeste}

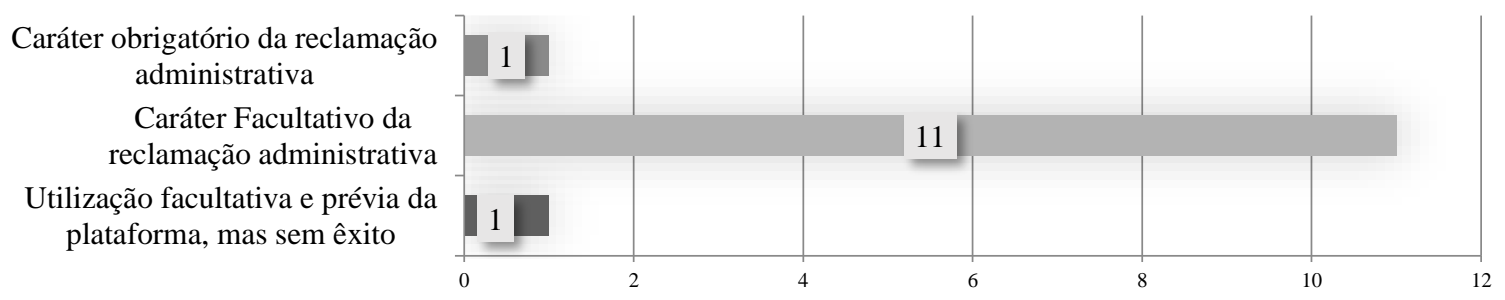

Da análise dos dados obtidos é possível perceber a importância da plataforma como mais um meio à disposição do consumidor para assegurar suas garantias e direitos, tendo ela sido citada pelos julgadores por várias vezes como uma sugestão e, em alguns, como uma imposição para o consumidor buscar a solução de seus conflitos.

Ainda, esmagadora maioria reconhece o caráter facultativo das reclamações administrativas pelo consumidor, em defesa do amplo acesso à justiça, independentemente dos

\footnotetext{
${ }^{84}$ TJDF, RI 0727184-06.2019.8.07.0016, Relator (a): Fernando Antonio Tavernard Lima, Data do Julgamento: 10/09/2019, Data da Publicação: 19/09/2019.

${ }^{85}$ TJDF, Apelação 0706696-12.2018.8.07.0001, Relator (a): Hector Valverde Santana, Data do Julgamento: 27/02/2019, Data da Publicação: 19/03/2019.

${ }^{86}$ TJDF, Apelação 0736148-04.2017.8.07.0001, Relator (a): Cesar Loyola, Data do Julgamento: 31/10/2018, Data da Publicação: 14/11/2018.
} 
canais disponíveis que ele pretenda ou se sinta à vontade para usar. Aliás, a não obrigatoriedade da plataforma também foi defendida pela Comissão Especial de Defesa do Consumidor da $\mathrm{OAB}$, a qual emitiu uma nota técnica ${ }^{87}$ nesse sentido.

O que muda, conforme se depreende das análises dos julgados, é o reconhecimento de algumas situações de danos morais, conforme o consumidor tenha ou não manejado previamente a plataforma, o que ressalta a importância dela como um instrumento de comprovação da tentativa do consumidor em resolver e da desídia do fornecedor em colaborar, o que pode ensejar os danos morais, fundamentados, por exemplo, na teoria da perda do tempo útil, conforme usada por um dos julgados.

Outro aspecto é que poderia ocorrer uma perspectiva mais dialogada entre fornecedor e consumidor, envolvendo renegociação, e não se esgotar, apenas numa resposta do fornecedor no prazo de 10 dias, quando ainda há a fase administrativa.

Por outro lado, verifica-se que a plataforma também é valiosa fonte de informação e de dados no intuito dela contribuir, por exemplo, quando o Ministério Público coleta informações, respostas, dados. É o caso se o órgão Ministerial, à medida que verifica grande quantidade de consumidores reclamando sobre a mesma cláusula do contrato ou de alguma outra situação, dito órgão valer-se das reclamações para justificar o manejo da tutela coletiva.

Ademais, em que pese não seja possível depreender da leitura dos julgados se o consumidor se enquadra numa das situações existenciais vulneráveis - superendividados, analfabetas, nível de escolaridade reduzida - seria importante destacar a necessidade de se levar em conta proteção especial para essas categorias de consumidores.

\footnotetext{
${ }^{87} \mathrm{OAB}$. Em nota técnica, OAB aponta mau uso de plataforma de conciliação para consumidores. Disponível em: https://www.oab.org.br/noticia/57651/em-nota-tecnica-oab-aponta-mau-uso-de-plataforma-de-conciliacao-paraconsumidores. Acesso em: 17 out. 2019.
} 


\section{CONCLUSÃO}

A plataforma consumidor.gov.br foi analisada sob a perspectiva de uma sociedade de hiperconsumo, uma sociedade em movimento, que está cada vez mais utilizando de novas tecnologias para buscar resolver seus conflitos.

A priori, foi exposta a estrutura da plataforma consumidor.gov.br, ou seja, uma ferramenta enquanto uma política pública que busca harmonização e facilitação de contato nas relações consumeristas em obediência as suas normas regulamentadoras. Em seguida, foi feita uma breve relação da plataforma com a Política Nacional das Relações de Consumo.

Pelos dados obtidos pela plataforma, foi possível verificar expressiva aceitação da plataforma por parte dos consumidores, ou seja, os consumidores que dela se utilizaram, a reconheceram como uma importante ferramenta de aproximação com seus fornecedores.

Também foi feita pesquisa sobre os julgados que abordam sobre ela. O que se destaca dos julgados colacionados é o reconhecimento da natureza facultativa, não só de dita plataforma como de outros canais administrativos (SAC, Agências, PROCONS), do uso deles pelos consumidores.

Nota-se, ainda certa resistência, em algumas decisões de primeira instância, as quais procuram exigir do consumidor que ele tente solucionar administrativamente seu problema com o fornecedor.

Dentre os julgados, também, um deles associa o uso da plataforma como mecanismo que evita o desperdício do tempo pelo consumidor, demonstrando que, se ocorrer esse desperdício, pode ser causa ensejadora de danos morais ao consumidor; outros, ressaltaram a utilização prévia da plataforma pelo consumidor, mas ele persistiu em judicializar outras pretensões, embora originárias do mesmo fato que tinha motivado a reclamação originária então solucionada.

Ademais, foi possível perceber pela análise dos dados produzidos pela própria plataforma que ainda é necessária maior divulgação sobre sua existência e funcionamento, haja vista que muitos consumidores informaram não saber sobre todos os recursos por ela disponibilizados e, caso soubessem, poderiam se utilizar mais da referida plataforma, e 
obviamente, tornar-se-ia ela, uma ferramenta para maior desjudicialização dos conflitos de consumo, vez que, conforme reconhecido até mesmo em um dos julgados, ela caracteriza-se por ser de fácil acesso, em virtude de poder ser utilizada a qualquer tempo e em qualquer lugar pelo consumidor, bastando, para tanto, um celular.

O canal digital de diálogo direto entre consumidor e fornecedor desenvolvido pela Secretaria é importante e, juntamente com os demais meios alternativos, como os PROCONS, deve, cada vez mais, ser aperfeiçoado e divulgado para que continue contribuindo para a desjudicialização dos conflitos de consumo, bem como contribuindo para fortalecer a autonomia do consumidor, porém, respeitadas as situações de vulnerabilidade, e principalmente, os hipervulneráveis, cuja plataforma tem que se equipar e aperfeiçoar-se para protegê-los e, assim, potencializar o uso dela ante os problemas novos que se debruçam nos conflitos de consumo; em suma o intuito é promover o acesso à justiça no seu sentido mais amplo e mais efetivo por meio de soluções mais rápida, menos custosa e menos desgastante para o polo vulnerável da relação de consumo.

\section{REFERÊNCIAS BIBLIOGRÁFICAS}

ALMEIDA, Tatiane Nunes Viana de; RAMOS, Anatália Saraiva Martins. Os impactos das reclamações On-line na lealdade dos consumidores: um estudo experimental. Revista de Administração Contemporânea, v. 16, n. 5, (2012). [Disponível em: http://www.scielo.br/scielo.php?script=sci_arttext\&pid=S1415-65552012000500003. Acesso em: 26 out. 2019].

BARROS, João Pedro Leite. Arbitragem Online em conflitos de consumo. São Paulo, Tirantto Blanch, 2019.

BELTRAME, Adriana; CHAIB; André Nunes; SILVA, René Marc da Costa Silva. O multiculturalismo e a globalização como princípios para uma internacionalização do direito. Padê, v. 2, n. 1 (jan./jun. 2008) [Disponível em: <https://www.publicacoesacademicas.uniceub.br/pade/article/view/583/531> Acesso $31 \mathrm{de}$ dezembro de 2019].

BOLETIM SINDEC 2018. Secretaria Nacional do Consumidor - SENACON (2018). [Disponível em: https://www.justica.gov.br/news/collective-nitf-content1552676889.94/arquivos/boletim-sindec-2018.pdf/view. Acesso 21 dez2019].

BRASIL. Decreto $n^{\circ} 2.181$, de 20 de março de 1997. Dispõe sobre a organização do Sistema Nacional de Defesa do Consumidor - SNDC, estabelece as normas gerais de aplicação das 
sanções administrativas previstas na Lei $\mathrm{n}^{\circ}$ 8.078, de 11 de setembro de 1990, revoga o Decreto $\mathrm{N}^{\mathrm{o}}$ 861, de 9 julho de 1993, e dá outras providências. Disponível em: http://www.planalto.gov.br/ccivil_03/decreto/D2181.htm. Acesso em: 25 out. 2019.

BRASIL. Decreto ${ }^{\circ}$ 7.963, de 15 de março de 2013. Institui o Plano Nacional de Consumo e Cidadania e cria a Câmara Nacional das Relações de Consumo. Disponível em: http://www.planalto.gov.br/ccivil_03/_Ato2011-2014/2013/Decreto/D7963.htm. Acesso em 15 dez. 2019.

BRASIL. Decreto $n^{\circ}$ 8.573, de 19 de novembro de 2015. Plataforma consumidor.gov.br. Dispõe sobre o Consumidor.gov.br, sistema alternativo de solução de conflitos de consumo, e dá outras providências. Disponível em: http://www.planalto.gov.br/ccivil_03/_ato20152018/2015/decreto/D8573.htm. Acesso em: 13 set. 2019.

BRASIL. Decreto ${ }^{\circ}$ 10.197, de 2 de janeiro de 2020. Altera o Decreto $n^{\circ} 8.573$, de 19 de novembro de 2015, para estabelecer o Consumidor.gov.br como plataforma oficial da administração pública federal direta, autárquica e fundacional para a autocomposição nas controvérsias em relações de consumo. [Disponível em: <http://www.planalto.gov.br/ccivil_03/_ato2019-2022/2020/decreto/D10197.htm> Acesso 13 janeiro 2020].

BRASIL. Lei no . 8.078, de 11 de setembro de 1990. Código de Defesa do Consumidor. Dispõe sobre a proteção do consumidor e dá outras providências. Disponível em: http://www.planalto.gov.br/ccivil_03/Leis/L8078.htm. Acesso em: 19 out. 2019.

BRASIL. Portaria $n^{\circ}$ 15, de 27 de Março de 2020. Determina o cadastro de empresas na plataforma Consumidor.gov.br para viabilizar a mediação via internet, pela Secretaria Nacional do Consumidor, dos conflitos de consumo notificados eletronicamente, nos termos do art. 34 do Decreto no 2.181, de 20 de março de 1997. [Disponível em: http://www.in.gov.br/web/dou//portaria-n-15-de-27-de-marco-de-2020-250710160. Acesso em 20 abril 2020].

CAETANO, Luiz Antunes. Arbitragem e Mediação: rudimentos. São Paulo: Atlas, 2002.

CARVALHO, Diógenes Faria de; BAMBIRRA, Felipe Magalhães. Política Nacional de Defesa do Consumidor: apontamentos necessários entre as bases de proteção e os mecanismos de solução de conflito. Revista de Direito do Consumidor, vol. 128 (Mar-Abr/2020).

COMITÊ GESTOR DA INTERNET NO BRASIL; Pesquisa sobre o uso das Tecnologias de Informação e Comunicação nos domicílios brasileiros: TIC Domicílios 2018. 16. ed. São Paulo: Grappa Marketing Editorial, 2019.

CONSUMIDOR.GOV.BR. Como aderir- Empresas. Disponível em: https://www.consumidor.gov.br/pages/conteudo/publico/2.Acesso em 15 dez. 2019.

CONSUMIDOR.GOV.BR. Conheça o Consumidor.gov.br. Disponível em: https://www.consumidor.gov.br/pages/conteudo/publico/1. Acesso em: 15 ago. 2019.

CONSUMIDOR.GOV.BR. Indicadores. Disponível em: https://www.consumidor.gov.br/pages/indicador/infografico/abrir. Acesso em: 05 dez. 2019. 
CONSUMIDOR.GOV.BR. Quem somos. Disponível em: https://www.consumidor.gov.br/pages/conteudo/publico/4.Acesso em 15 dez. 2019.

GARTH, Bryant; CAPELLETTI, Mauro. Acesso à justiça [Trad. Ellen Gracie Northfleet]. Porto Alegre, Sergio Antonio Fabris, 1988.

IGREJA, Rebecca Lemos. O direito como objeto de estudo empírico: o uso de métodos qualitativos no âmbito da pesquisa empírica em direito. MACHADO, Maíra Rocha [Organização]. Pesquisar empiricamente o direito. São Paulo: Rede de Estudos Empíricos em Direito, 2017.

JUSTIÇA EM NÚMEROS 2019. Conselho Nacional de Justiça - CNJ (2019). Disponível em: $\leq$ https://www.cnj.jus.br/wpcontent/uploads/conteudo/arquivo/2019/08/justica_em_numeros20190919.pdf>. Acesso 19 out. 2019.

LIPOVETSKY, Gilles. A felicidade paradoxal: ensaios sobre a sociedade de hiperconsumo [Trad. Maria Lucia Machado]. São Paulo, Companhia das Letras, 2007.

MACHADO, Maíra Rocha. Pesquisar empiricamente o direito. São Paulo: Rede de Estudos Empíricos em Direito, 2017.

MANCUSO, Rodolfo de Camargo. Acesso à justiça: condicionantes legítimas e ilegítimas. São Paulo, Revista dos Tribunais, 2011.

MARCONI, Marina de. Andrade; LAKATOS, Eva Maria. Fundamentos de metodologia científica. 5. ed. São Paulo: Atlas S.A, 2003.

MARQUES, Cláudia Lima. A nova noção de fornecedor no consumo compartilhado: um estudo sobre as correlações do pluralismo contratual e o acesso ao consumo. Revista de direito do consumidor, v. 111 (Mai-Jun/2017).

MINISTÉRIO DA JUSTIÇA E SEGURANÇA PÚBLICA. Aumentam os atendimentos em portal do Consumidor. Disponível em: https://www.justica.gov.br/news/collective-nitf-content1551466308.51. Acesso em: 19 out. 2019.

MIRAGEM, Bruno. Curso de Direito do Consumidor. 6. ed. São Paulo: Revista dos Tribunais LTDA, 2016.

MONTEIRO FILHO, Carlos Édison do Rêgo. O problema da massificação das demandas consumeristas: atuação do Procon e proposta de solução à luz do direito contemporâneo. Revista de direito do consumidor, v. 108: (nov-dez/2016).

NAÇÕES UNIDAS. OIT: quase 25 milhões de empregos podem ser perdidos no mundo devido à COVID-19 (18/3/2020). Disponível em: <https://nacoesunidas.org/oit-quase-25-milhoes-deempregos-podem-ser-perdidos-no-mundo-devido-a-covid-19/> Acesso: 13/4/2020. 
OAB. Em nota técnica, $\mathrm{OAB}$ aponta mau uso de plataforma de conciliação para consumidores. Disponível em: https://www.oab.org.br/noticia/57651/em-nota-tecnica-oab-aponta-mau-uso-deplataforma-de-conciliacao-para-consumidores. Acesso em: 17 out. 2019.

OZAKI, Adalton; VASCONCELLOS, Eduardo. A revolução digital. In POLIZELLI, Demerval L; OZAKI, Adalton [Organizadores]. Sociedade da informação: os desafios da era da globalização e da gestão do conhecimento. São Paulo, Saraiva, 2008 [Versão E-book].

SILVA, Paulo Eduardo Alves da. Pesquisas em processos judiciais. MACHADO, Maíra Rocha [Organização]. Pesquisar empiricamente o direito. São Paulo: Rede de Estudos Empíricos em Direito, 2017.

SLADE, Giles. Made to break: technology and obsolescence in America. Cambridge, Harvard University Press, 2006.

SOUSA, João Paulo Alexandre de. Defesa do consumidor e políticas públicas: um estudo sobre o Consumidor.gov.br. Dissertação (Monografia apresentada ao curso Gestão de Políticas Públicas) - Universidade de Brasilia, Brasilia, 2014 (Disponível em: http://bdm.unb.br/bitstream/10483/9444/1/2014_JoaoPauloAlexandreDeSousa.pdf. Acesso em: 12 dez. 2019).

TARTUCE, Fernanda. Mediação nos conflitos civis. Rio de Janeiro, Forense, São Paulo, 2008.

TOFFLER, Alvin. A terceira onda: a morte do industrialismo e o nascimento de uma nova civilização. [Tradução de João Távora]. Rio de Janeiro: Record, 2012.

VERBICARO, Dennis. Consumo e cidadania: identificando os espaços políticos de atuação qualificada do consumidor. Rio de Janeiro, Lumen Juris, 2017.

WHO - WORLD HEALTH ORGANIZATION. WHO Director-General'sopeningremarksatthe media briefing on COVID-19 (11/3/2020) [Disponível em: $<$ https://www.who.int/dg/speeches/detail/who-director-general-s-opening-remarks-at-themedia-briefing-on-covid-19---11-march-2020>. Acesso: 8 abr 2020].

Data de Submissão: 02/10/2020

Data de Aceite: 19/03/2021 